\title{
Authigenic formation of $\mathrm{Ca}-\mathrm{Mg}$ carbonates in the shallow alkaline Lake Neusiedl, Austria
}

\author{
Dario Fussmann ${ }^{1}$, Avril Jean Elisabeth von Hoyningen-Huene ${ }^{2}$, Andreas Reimer ${ }^{1}$, Dominik Schneider ${ }^{2}$, \\ Hana Babková ${ }^{3}$, Robert Peticzka ${ }^{4}$, Andreas Maier ${ }^{4}$, Gernot Arp ${ }^{1}$, Rolf Daniel ${ }^{2}$, and Patrick Meister ${ }^{3}$ \\ ${ }^{1}$ Geobiology, Geoscience Centre, Georg-August-Universität Göttingen, Goldschmidtstraße 3, 37077 Göttingen, Germany \\ ${ }^{2}$ Genomic and Applied Microbiology and Göttingen Genomics Laboratory, Institute of Microbiology and Genetics, \\ Georg-August-Universität Göttingen, Grisebachstraße 8, 37077 Göttingen, Germany \\ ${ }^{3}$ Department of Geodynamics and Sedimentology, University of Vienna, Althanstraße 14, 1090 Vienna, Austria \\ ${ }^{4}$ Department of Geography and Regional Research, University of Vienna, Althanstraße 14, 1090 Vienna, Austria
}

Correspondence: Dario Fussmann (dario.fussmann@uni-goettingen.de)

Received: 15 November 2019 - Discussion started: 5 December 2019

Revised: 18 February 2020 - Accepted: 11 March 2020 - Published: 16 April 2020

\begin{abstract}
Despite advances regarding the microbial and organic-molecular impact on nucleation, the formation of dolomite in sedimentary environments is still incompletely understood. Since 1960, apparent dolomite formation has been reported from mud sediments of the shallow, oligohaline and alkaline Lake Neusiedl, Austria. To trace potential dolomite formation or diagenetic alteration processes in its deposits, lake water samples and sediment cores were analyzed with respect to sediment composition, hydrochemistry and bacterial community composition. Sediments comprise $20 \mathrm{~cm}$ of homogenous mud with $60 \mathrm{wt} \%$ carbonate, which overlies dark-laminated consolidated mud containing $50 \mathrm{wt} \%$ carbonate and plant debris. Hydrochemical measurements reveal a shift from oxic lake water with $\mathrm{pH} 9.0$ to anoxic sediment pore water with $\mathrm{pH} 7.5$. A decrease in $\mathrm{SO}_{4}^{2-}$ with a concomitant increase in $\Sigma \mathrm{H}_{2} \mathrm{~S}$ and $\mathrm{NH}_{4}^{+}$from 0 to $15 \mathrm{~cm}$ core depth indicates anaerobic heterotrophic decomposition, including sulfate reduction. The bacterial community composition reflects the zonation indicated by the pore water chemistry, with a distinct increase in fermentative taxa below $15 \mathrm{~cm}$ core depth.

The water column is highly supersaturated with respect to (disordered) dolomite and calcite, whereas saturation indices of both minerals rapidly approach zero in the sediment. Notably, the relative proportions of different authigenic carbonate phases and their stoichiometric compositions remain constant with increasing core depth. Hence, evidence for $\mathrm{Ca}-\mathrm{Mg}$ carbonate formation or ripening to dolomite is lacking within
\end{abstract}

the sediment of Lake Neusiedl. As a consequence, precipitation of high-magnesium calcite (HMC) and protodolomite does not occur in association with anoxic sediment and sulfate-reducing conditions. Instead, analytical data for Lake Neusiedl suggest that authigenic HMC and protodolomite precipitate from the supersaturated, well-mixed aerobic water column. This observation supports an alternative concept to dolomite formation in anoxic sediments, comprising $\mathrm{Ca}-$ $\mathrm{Mg}$ carbonate precipitation in the water column under aerobic and alkaline conditions.

\section{Introduction}

Dolomite $\left(\mathrm{CaMg}\left(\mathrm{CO}_{3}\right)_{2}\right)$ is the most abundant carbonate mineral in Earth's sedimentary record. It has rarely been observed forming in recent environments. Instead, most occurrences of large dolomite deposits in the geological record are the result of pervasive dolomitization of precursor carbonates by fluids with high $\mathrm{Mg}$ : Ca ratios and temperatures during burial (e.g., Machel, 2004). In contrast, the formation of dolomite near the sediment surface, so-called penecontemporaneous dolomite (Machel, 2004, and references therein), or even primary precipitation in shallow aquatic environments is often difficult to trace in the rock record and capture in modern environments. The difficulty in capturing ongoing dolomite formation is due to its peculiar kinetics, which are still incompletely understood despite intense laboratory and 
field experiments. Dolomite does not form in sites where sufficient $\mathrm{Ca}, \mathrm{Mg}$ and carbonate ions are provided, which is generally explained by the high kinetic barrier of dolomite nucleation and growth (e.g., Lippmann, 1973).

Based on the presence of sulfate-reducing bacteria (SRB), Vasconcelos et al. (1995) proposed a microbial model, in which sulfate-reducing bacteria mediate carbonate precipitation, while Brady et al. (1996) consider sulfate ions to be inhibitors for dolomite growth. Further experiments were performed with various different organisms, such as denitrifiers (Rivadeneyra et al., 2000), methanogenic archaea (Roberts et al., 2004) and aerobic halophilic bacteria (Sánchez-Román et al., 2009). All of these studies showed aggregate formation of carbonate minerals with the characteristic $d_{104}$ peak of dolomite under X-ray diffraction, hence supporting a microbial factor in dolomite formation. It has been hypothesized that dolomite nucleation is mediated by microbial extracellular polymeric substances (EPSs; Bontognali et al., 2014). However, Gregg et al. (2015) re-analyzed the X-ray diffraction data of many of the aforementioned microbial experiments, demonstrating that microbial dolomite products lack typical ordering reflections in XRD spectra and are in fact very high magnesium calcite (VHMC or "protodolomite"). In further studies sulfide (F. Zhang et al., 2013), dissolved organic matter (Frisia et al., 2018) or clay minerals (Liu et al., 2019) were suggested to favor protodolomite nucleation in pore fluids. Nevertheless, it is not entirely clear which of these factors play a fundamental role in natural environments and how the specific reaction mechanisms work.

While the concept that dolomite forms within sediments mediated by anaerobic microbial processes and their extracellular polymeric substances is widely acknowledged, another aspect should be taken into account: the site of dolomite formation may not always coincide with the location where the mineral is found due to relocation after precipitation. Several studies describe unlithified dolomite precipitation in warm, arid and hypersaline marine environments, like coastal sabkhas (Illing et al., 1965; Bontognali et al., 2010; Court et al., 2017), coastal lakes, such as Lagoa Vermelha in Brazil (Vasconcelos and McKenzie, 1997; van Lith et al., 2002; Sánchez-Román et al., 2009), and ephemeral lakes along the Coorong lagoon in southern Australia (von der Borch, 1976; Rosen et al., 1989; Warren, 1990; Wright and Wacey, 2005). Dolomite precipitation is further reported in endorheic hypersaline lakes, e.g., Qinghai Lake in Tibet (Deng et al., 2010), Lake Acıgöl (Turkey; Balci et al., 2016) and alkaline playa lakes such as Deep Springs Lake in California (Meister et al., 2011).

Another location where $\mathrm{Ca}-\mathrm{Mg}$ carbonate is formed can be found in Turkey, where McCormack et al. (2018) describe dolomite in Quaternary sediments from Lake Van, which is suggested to have formed at the sediment-water interface characterized by varying salinities and low temperatures. These dolomite-bearing deposits have been related to the onset of a falling paleo-lake level, hence changing hydrochem- ical conditions. Importantly, McCormack et al. (2018) locate the formation of dolomite near the sediment-water interface, where it is presumably related to microbial EPS. However, this area is also exposed to significant fluctuations in $\mathrm{pH}$, temperature and supersaturation. Precipitation experiments conducted by Deelman (1999) have shown that dolomite can form due to such fluctuations in $\mathrm{pH}$ and temperature. Hence, they agree with Ostwald's step rule because dolomite formation happens via undersaturation of other metastable carbonate phases.

Lake Neusiedl is a water body that precipitates $\mathrm{Ca}-\mathrm{Mg}$ carbonate at exceptionally low salinity $\left(1-2 \mathrm{~g} \mathrm{~L}^{-1}\right)$. It is a shallow and seasonally evaporative lake in the proximity of Vienna, Austria. Schroll and Wieden (1960) first reported the occurrence of poorly crystallized dolomite (notable by its broad XRD reflections) at this locality, and Müller et al. (1972) related its formation to diagenetic alteration of high-magnesium calcite (HMC). The $\mathrm{Mg}$ : Ca ratios in Lake Neusiedl are unusually high $(>7)$ compared to freshwater lakes, which favor the precipitation of HMC (Müller et al., 1972). Little is known about the crystallization paths of the $\mathrm{Ca}-\mathrm{Mg}$ carbonate phases in this lake, in particular whether they form in the anoxic sediment or oxic water column and if early diagenetic alteration to dolomite ("ripening") takes place.

We revisit the formation of dolomite in Lake Neusiedl by comparing the sediment geochemical and in situ pore water data and critically evaluating the location of precipitation. This approach has been used to study dolomite formation in Lagoa Vermelha (van Lith et al. 2002; Moreira et al., 2004) or in Deep Springs Lake (Meister et al., 2011). Since 2005, in situ pore water extraction via rhizon samplers has been applied for geoscientific research questions (SeebergElverfeldt et al., 2005), and several in situ pore water studies were conducted using this technique (e.g., Bontognali et al., 2010; Birgel et al., 2015; Steiner et al., 2018). Comparable in situ pore water data from an oligohaline seasonally evaporative lake, which address the question of authigenic $\mathrm{Ca}-\mathrm{Mg}$ carbonate precipitation, are absent so far. We further provide bacterial community analyses to address the potential role of microbes and their metabolisms in a carbonate mineral precipitation or alteration pathway. Hence, our study has three goals: (i) finding indications for the origin of $\mathrm{Ca}-\mathrm{Mg}$ carbonate formation, (ii) evaluating the microbiological and geochemical conditions and their influence on carbonate saturation, and (iii) discussing which factors drive the formation of $\mathrm{Ca}-\mathrm{Mg}$ carbonates in Lake Neusiedl.

\section{Study area}

Lake Neusiedl, situated at the Austrian-Hungarian border, is the largest endorheic lake in western Europe. It is located in the Little Hungarian Plain, a transition zone between the Eastern Alps and the Pannonian Basin in central 
Hungary. The region has been tectonically active since the early Miocene (Horváth, 1993) and is affected by NE-SWtrending normal faults. This early Miocene tectonic activity included the closing of the Central Paratethys Sea and the formation of Lake Pannon about 11.6 million years ago. This ancient water body was characterized by highly fluctuating water levels that caused the deposition of local evaporite layers, which influence the salinity of today's deeper aquifers in the area (Piller et al., 2007; Krachler et al., 2018). The present topography of the Little Hungarian Plain is the result of ongoing local uplift and subsidence, which commenced in the latest Pliocene (Zámolyi et al., 2017). Elevated regions are represented by the Rust and Leitha hills, which are horst-like structures located west of Lake Neusiedl. Northward, the water body is separated from the Vienna Basin by the raised Parndorf plateau, which has a $25-45 \mathrm{~m}$ higher surface elevation than the lake area. South- and eastward, Lake Neusiedl is surrounded by flats, namely the Hanság and Seewinkel plain. Despite its proximity to the Alps, the region surrounding Lake Neusiedl did not have an ice cover during the last glacial maximum. Hence, its morphology is shaped by periglacial erosion and sedimentation (van Husen, 2004). Throughout the Seewinkel plain, Pannonian marine to brackish sediments are largely covered by fluvioglacial gravels. The gravels thin out westwards and are thus missing beneath parts of Lake Neusiedl, where fine-grained, unlithified lacustrine mud directly overlies compacted Pannonian strata (Loisl et al., 2018). The absence of a gravel layer has made the former lake area vulnerable to aeolian erosion, favoring the formation of the present-day flat trough over tectonic subsidence (Zámolyi et al., 2017).

The surface area of the water body spreads over $315 \mathrm{~km}^{2}$, with a maximum depth of $1.8 \mathrm{~m}$. With a salinity of 1$2 \mathrm{~g} \mathrm{~L}^{-1}$ and elevated $\mathrm{pH}$ values (> 8.5), the water chemistry differs significantly from that of freshwater lakes (salinity: $<0.5 \mathrm{~g} \mathrm{~L}^{-1} ; \mathrm{pH}$ : 6.5-7.5). Increased amounts of sodium and bicarbonate ions mainly contribute to the lake's soda-like character (Herzig, 2014). Furthermore, the $\mathrm{Mg}$ : Ca ratio is unusually high in comparison to freshwater lakes (Krachler et al., 2012). Permanent surface water inflow is mainly provided by the Rákos and the Wulka streams, which drain a catchment area that is approximately 2.6 times the size of Lake Neusiedl $\left(1120 \mathrm{~km}^{2}\right)$. Thus, their contribution to the lake's water balance is negligible compared to the significantly higher input from precipitation, providing $80 \%-90 \%$ of the lake water (Herzig and Dokulil, 2001). As a result of its shallowness and the endorheic drainage system, the lake is very vulnerable to climatic changes, which highly influence the water level, water volume and, hence, the surface area of the lake throughout the year and over the centuries. In the past, Lake Neusiedl was characterized by highly fluctuating water levels and desiccation events (Moser, 1866), the last of which dates back between 1865 and 1870. Since 1910, the lake's water outflow can be regulated by the artificial Hanság or Einser canal in case of severe flooding events. The canal is located at the lake's southeastern shore (Fig. 1).

More than half $\left(178 \mathrm{~km}^{2}\right)$ of Lake Neusiedl's surface area is covered with reed. Due to its wind exposure and shallowness, the water column of the open water area is well mixed and contains high amounts of suspended particles. The wind sheltering effect of Phragmite spears, in contrast, leads to clearer water in the reed belt. Clastic input into the water body is minor and reflects the mineralogical composition of the western neighboring Rust and Leitha hills, which are characterized by crystalline rocks of the Eastern Alpine basement and Miocene marine carbonates ("Leithakalk"; Fig. 1). The deposits forming the present bed of Lake Neusiedl consist of fine-grained mud, which mainly contains typical authigenic carbonate phases such as $\mathrm{Mg}$ calcite and protodolomite (Löffler, 1979). Those phases can clearly be distinguished from pure calcite, which is considered to be allochthonous in the sedimentary environment of Lake Neusiedl (Müller et al., 1972). It is noteworthy that the mud volume doubled in the time from 1963 to 1988, leading to an increase in the volumetric mud / water ratio from $36: 64$ in 1963 to $49: 51$ in 1988. This mud layer covers the whole lake area and would yield an average thickness of $64 \mathrm{~cm}$, assuming an equal distribution across the lake basin (Bácsatyai, 1997). The thickness of soft sediment can increase up to $1 \mathrm{~m}$ at the border of the reed belt and open water, where Phragmite spears act as sediment traps for current driven, suspended particles (Löffler, 1979).

\section{Material and methods}

\subsection{Sampling and field measurements}

The sampling campaign at Lake Neusiedl was performed in August 2017 in the bay of Rust $\left(47^{\circ} 48^{\prime} 12.929^{\prime \prime} \mathrm{N}\right.$, $16^{\circ} 42^{\prime} 33.635^{\prime \prime} \mathrm{E}$ ), situated at the lake's central western shore. A pedalo boat was utilized to enable sampling approximately $500 \mathrm{~m}$ offshore. Physicochemical parameters of the lake water were measured directly in the field using a WTW Multi 3430 device equipped with a WTW Tetracon 925 conductivity probe, a WTW FDO 925 probe for dissolved $\mathrm{O}_{2}$, and a WTW Sentix 940 electrode for temperature and $\mathrm{pH}$ (Xylem, Rye Brook, NY, USA), calibrated against standard pH buffers 7.010 and 10.010 (HI6007 and HI6010, Hanna Instruments, Woonsocket, RI, USA; standard deviation $\leq 2 \%$ ). Lake water was retrieved from a depth of $10 \mathrm{~cm}$ with a $500 \mathrm{~mL}$ SCHOTT-DURAN glass bottle without headspace from which subsamples for anion, nutrient and total alkalinity determination were distributed into $100 \mathrm{~mL}$ polyethylene (PE) and $250 \mathrm{~mL}$ SCHOTT-DURAN glass bottles (SCHOTT, Mainz, Germany). For cation analysis, a $50 \mathrm{~mL}$ aliquot was filtered through membrane filters with a pore size of $0.7 \mu \mathrm{m}$ (Merck, Darmstadt, Germany) into a PE bottle and acidified with $100 \mu \mathrm{L} \mathrm{HNO}_{3}$ (sub-boiled). 


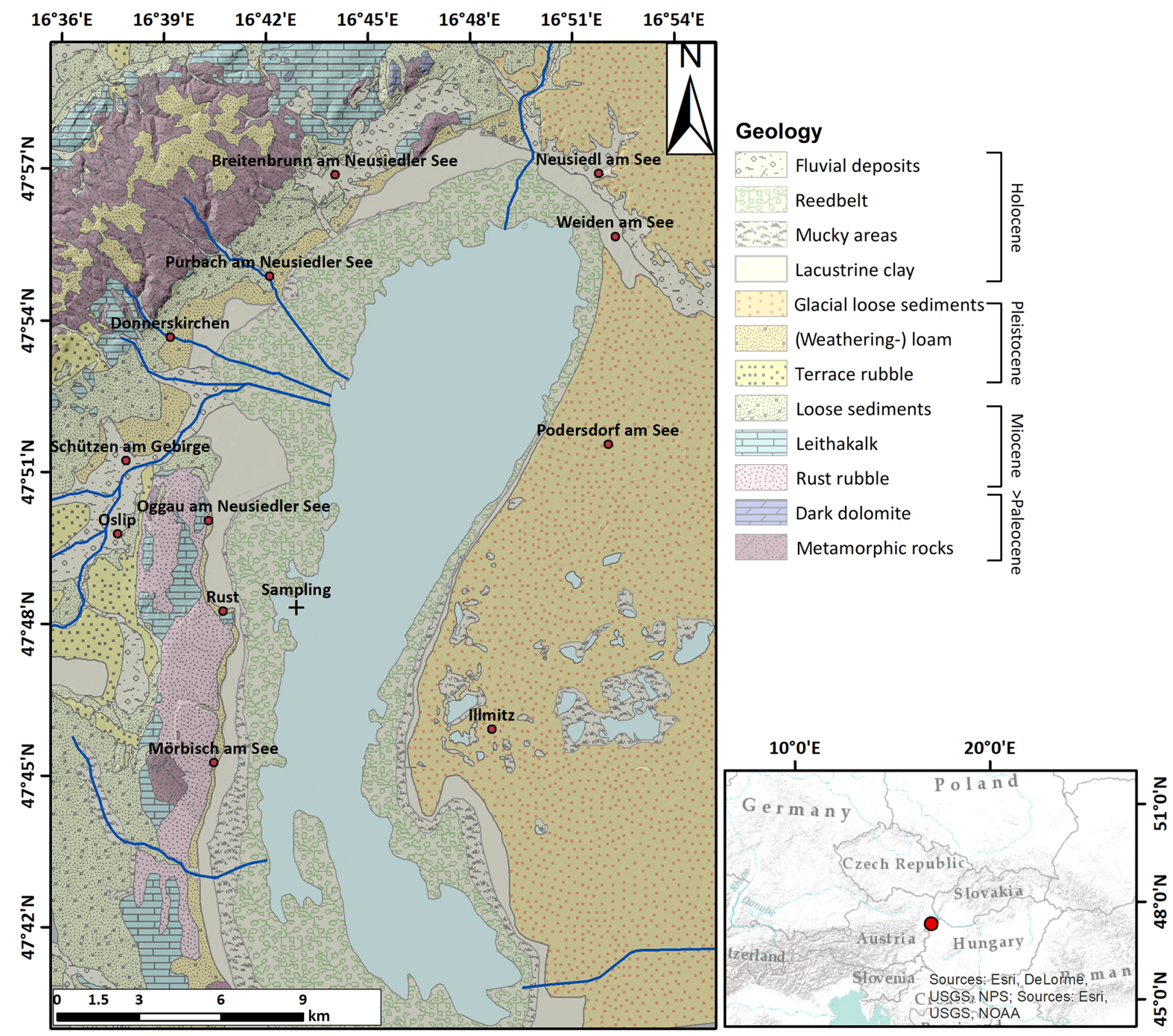

Figure 1. Lake Neusiedl and its surrounding geology, redrawn and simplified after Herrman et al. (1993).

Total alkalinity was determined via titration within $3 \mathrm{~h}$ after sampling using a handheld titration device and $1.6 \mathrm{~N} \mathrm{H}_{2} \mathrm{SO}_{4}$ cartridges (Hach Lange, Düsseldorf, Germany; standard deviation $\leq 1.5 \%$ ).

Five sediment cores, with the sample codes LN-K01, LN$\mathrm{K} 02$, LN-K03, LN-K04 and LN-K05, were retrieved using PVC tubes $(6.3 \mathrm{~cm}$ diameter; Uwitec, Mondsee, Austria) in approximately $30 \mathrm{~cm}$ lateral distance. All cores were 30 to $40 \mathrm{~cm}$ in length and were used for sediment, pore water and bacterial community profiling. Cores LN-K01 and LN-K02 were subsampled and treated for bacterial community profiling as described in von Hoyningen-Huene et al. (2019) directly after recovery. Cores LN-K03, LN-K04 and LN-K05 were hermetically sealed after recovery and stored upright at temperatures close to their natural environment $\left(22 \pm 2{ }^{\circ} \mathrm{C}\right)$.
Effects of pressure differences are neglectable in the present case because the cores were sampled just below the lake floor.

\subsection{Petrographic, mineralogical and geochemical analyses}

Two cores, labeled LN-K04 and LN-K05, were used for sediment geochemical and petrographic analyses. Sediment dry density and porosity were calculated from the corresponding sediment weights and volumes. For bulk organic and inorganic carbon content detection, sediment increments of $2.5 \mathrm{~cm}$ were subsampled from core LN-K04. They were freeze-dried and powdered with a ball mill before they were measured by a LECO RC612 (Leco, St. Joseph, MI, USA) 
multi-phase carbon and water determination device. For calibration, Leco synthetic carbon (1 and 4.98 carbon \%) and Leco calcium carbonate (12 carbon \%) standards were used. The same increments were utilized for CNS elemental detection, which was operated with a Euro EA 3000 Elemental Analyser (HEKAtech, Wegberg, Germany); 2,5-bis(5tert-benzoxazol-2-yl)thiophene BBOT and atropine sulfate monohydrate (IVA Analysetechnik, Meerbusch, Germany) were provided as reference material. Analytical accuracy of all analyses was better than $3.3 \%$.

XRD analyses were conducted with identical increments at the Department of Geodynamics and Sedimentology in Vienna by a PANanalytical (Almelo, Netherlands) X'pert Pro device $\left(\mathrm{CuK} \alpha\right.$ radiation, $2 \theta$ refraction range of $2-70^{\circ}$ and a step size of $0.01^{\circ}$ ). Semi-quantitative phase composition analysis was performed with Rietveld refinement of peak intensities by using MAUD (version 2.8; Lutterotti et al., 2007). To ensure a better reproducibility of the semiquantitative XRD analysis, Rietveld-refined results were compared and correlated with carbon data retrieved from the aforementioned LECO RC612 device.

In core $\mathrm{LN}-\mathrm{K} 05$, sediment increments of $5 \mathrm{~cm}$ were subsampled for thin sectioning and light microscopic observations. To ensure a continuous section, rectangular steel meshes, $5 \mathrm{~cm}$ in length, were placed along the sediment column. These steel meshes, filled with soft sediment, were then embedded in LR White resin (London Resin Company, Reading, United Kingdom) after a dehydration procedure with ethanol. During dehydration, the sediments were treated with SYTOX Green nucleic acid stain (Invitrogen, Carlsbad, CA, USA) to stain eukaryotic cell nuclei and prokaryotic cells for fluorescence microscopy. Samples were cured for $24 \mathrm{~h}$ at $60^{\circ} \mathrm{C}$ before thin-section preparation. The thin sections were ground down to a thickness of 40 to $50 \mu \mathrm{m}$ and then capped with a glass cover. Petrographic observations were conducted with a petrographic and a laser-scanning microscope (ZEISS, Oberkochen, Germany; 1sm excitation: 543, 488, 633 nm; laser unit: Argon/2, HeNe543, HeNe633).

For scanning electron microscopy, non-capped unpolished thin-section fragments and freeze-dried loose sediment from cores $\mathrm{LN}-\mathrm{K} 05$ and $\mathrm{LN}-\mathrm{K} 04$ were placed on $12.5 \mathrm{~mm}$ plano carriers and sputtered with a platinum-palladium mixture. Field emission scanning electron microscopy was conducted with a Gemini Leo 1530 device (ZEISS, Oberkochen, Germany) with a coupled INCA x-act (Oxford Instruments, Abingdon, UK) EDX detector.

\subsection{Pore water analysis}

Redox potential and $\mathrm{pH}$ gradients were directly measured in the sediment of core $\mathrm{LN}-\mathrm{K} 03$ one week after sampling with a portable WTW 340i pH meter, equipped with an InLab Solids Pro pH electrode (Mettler Toledo, Columbus, OH, USA) and a Pt-5900 A redox electrode (SI Analytics, Mainz, Germany) through boreholes (standard deviation $\leq 2 \%$ ). Pore water was extracted from the core, using $5 \mathrm{~cm}$ CSS Rhizon samplers (Rhizosphere, Wageningen, Netherlands). Immediately after extraction, aliquots were fixed with $\mathrm{Zn}$ acetate for determination of total sulfide $\left(\Sigma \mathrm{H}_{2} \mathrm{~S}\right)$. Pore water alkalinity was determined using a modified Hach titration method with self-prepared $0.01 \mathrm{~N} \mathrm{HCl}$ cartridges as titrant. Major cation $\left(\mathrm{Ca}^{2+}, \mathrm{Mg}^{2+}, \mathrm{Na}^{+}, \mathrm{K}^{+}\right.$and $\left.\mathrm{Li}^{+}\right)$ and anion $\left(\mathrm{Cl}^{-}, \mathrm{F}^{-}, \mathrm{Br}^{-}, \mathrm{SO}_{4}^{2-}\right.$ and $\left.\mathrm{NO}_{3}^{-}\right)$concentrations of lake and pore water samples (including supernatants in the cores) were analyzed by ion chromatography with nonsuppressed and suppressed conductivity detection, respectively (Metrohm 820 IC/Metrosep C3 - 250 analytical column, Metrohm 883 Basic IC/Metrohm A Supp 5-250 analytical column; Metrohm, Herisau, Switzerland; standard deviation $\leq 2 \%$ ). Inductively coupled plasma mass spectrometry (ICP-MS; iCAP-Q, Thermo Fisher, Waltham, MA, USA) was used to determine $\mathrm{Sr}, \mathrm{Ba}, \mathrm{Fe}, \mathrm{Mn}, \mathrm{Rb}$ and $\mathrm{B}$ as control for the cation determination by ion chromatography (standard deviation $\leq 3 \%$ ).

Concentrations of $\mathrm{NH}_{4}^{+}, \mathrm{NO}_{2}^{-}, \mathrm{PO}_{4}^{3-}, \Sigma \mathrm{H}_{2} \mathrm{~S}$ and dissolved silica $\left(\mathrm{SiO}_{2(\mathrm{aq})}\right)$ were measured by photometric methods according to Grasshoff et al. (2009), using a SI Analytics UviLine 9400 spectrophotometer. In addition, methane and dissolved inorganic carbon (DIC) amounts were retrieved from a different core, sampled at the same locality in August 2017. Methane concentrations were determined from $5 \mathrm{~cm}^{3}$ sediment samples stored upside down in gas-tight glass bottles containing $5 \mathrm{~mL} \mathrm{NaOH}(5 \% \mathrm{w} / \mathrm{v})$. Aliquots of $5 \mathrm{~mL}$ headspace methane were transferred to evacuated $10 \mathrm{~mL}$ vials. The aliquots were analyzed with an automated headspace gas chromatograph (GC Agilent 7697A coupled to an Agilent 7890B auto sampler) at the University of Vienna. Methane concentrations were quantified at a runtime of $1.798 \mathrm{~min}$ by a flame ionization detector and a methanizer. For linear calibration, a standard series with the concentrations 1001, 3013 and 10003 ppb was used. DIC concentrations were retrieved by using a Shimadzu TOC-LCPH (Shimadzu, Kyoto, Japan) analyzer with an ASI-L autosampler and a reaction vessel containing a reaction solution of phosphoric acid $\left(\mathrm{H}_{3} \mathrm{PO}_{4}, 25 \%\right)$. The DIC was measured by conversion to carbon dioxide, which was detected by a NDIR detector.

All measured values were processed with the PHREEQC software package (version 3; Parkhurst and Appelo, 2013). The implemented phreeqc.dat and wateqf4.dat databases were used in order to calculate ion activities and $p \mathrm{CO}_{2}$ (partial pressure of $\mathrm{CO}_{2}$ ) of the water samples and mineral saturation states. The saturation indices of mineral phases are given as $\mathrm{SI}=\log \left(\mathrm{IAP} / \mathrm{K}_{\mathrm{SO}}\right)$.

\subsection{Bacterial 16S rRNA gene community profiling}

Two sediment cores labeled LN-K01 and LN-K02 were sampled for bacterial 16S rRNA gene-based community profiling. Each core was sampled in triplicate at every $2.5-5 \mathrm{~cm}$ 
of depth and the surface water filtered through a 2.7 (Merck, Darmstadt, Germany) and $0.2 \mu \mathrm{m}$ (Sartorius, Göttingen, Germany) filter sandwich. RNAprotect Bacteria Reagent (QIAGEN, Hilden, Germany) was immediately added to all samples in order to preserve the nucleic acids. Before storage at $-80^{\circ} \mathrm{C}$, the samples were centrifuged for $15 \mathrm{~min}$ at $3.220 \times \mathrm{g}$ and the RNAprotect Bacteria Reagent was decanted.

DNA was extracted and 16S rRNA genes were amplified and sequenced as described in detail by von HoyningenHuene et al. (2019). Briefly, DNA was extracted from $250 \mathrm{mg}$ of each homogenized sediment sample or one-third of each filter with the MoBio PowerSoil DNA isolation kit (MoBio, Carlsbad, CA, USA) according to manufacturer's instructions with an adjusted cell disruption step. Bacterial 16S rRNA genes were amplified in triplicate by PCR, with the forward primer D-Bact-0341-b-S-17 and the reverse primer S-D-Bact-0785-a-A-21 (Klindworth et al., 2013) targeting the V3-V4 hypervariable regions. Primers included adapters for sequencing on an Illumina MiSeq platform. PCR triplicates were pooled equimolar and purified with MagSi$\mathrm{NGS}^{\text {PREP }}$ magnetic beads (Steinbrenner, Wiesenbach, Germany) as recommended by the manufacturer and eluted in $30 \mu \mathrm{L}$ elution buffer (EB; Qiagen, Hilden, Germany).

PCR products were sequenced with the $\mathrm{v} 3$ Reagent kit on an Illumina MiSeq platform (San Diego, CA, USA) as described by Schneider et al. (2017). Sequencing yielded a total of 6044032 paired-end reads, which were quality-filtered (fastp, version 0.19.4; Chen et al., 2018), merged (PEAR, version 0.9.11; J. Zhang et al., 2013) and processed. This comprised primer-clipping (cutadapt, version 1.18; Martin, 2011), size-filtering, dereplication, denoising and chimera removal (VSEARCH, v2.9.1; Rognes et al., 2016). Taxonomy was assigned to the resulting amplicon sequence variants (ASVs; Callahan et al., 2017) via BLAST 2.7.1+ against the SILVA SSU 132 NR (Quast et al., 2012). After taxonomic assignment, 2263813 merged reads remained in the dataset. The resulting ASV abundance table was used for the visualization of community gradients along the cores (von Hoyningen-Huene et al., 2019). Data were analyzed using $\mathrm{R}$ (version 3.5.2; R Core Team, 2019) and RStudio (version 1.1.463; RStudio; R Core Team, 2016) using the base packages. Extrinsic domains, archaea and eukaryotes were removed from the ASV table for analysis. All ASVs with lower identity than $95 \%$ to database entries were assigned as unclassified. Replicates for each depth were merged and transformed into relative abundances, and all ASVs with an abundance $>0.5 \%$ were summarized by their phylogenetic orders. Putative functions of all orders were assigned according to literature on cultured bacterial taxa and the closest cultured relatives of the ASVs present in our samples. For uncultured taxa, functions were inferred from literature on genomic and metagenomic sequencing data (Table S6). The resulting table with relative abundances and functional assignments was used to generate bar charts in SigmaPlot (version 11; Systat Software, 2008).

\section{Results}

\subsection{Sediment petrography and mineralogy}

The cored sediment can be divided into three different lithological units. Unit I, in the first $15 \mathrm{~cm}$ below surface (b.s.), is characterized by homogenous, light to medium grey mud with very high water content and porosity $(>65 \mathrm{wt} \%, 0.67)$. The mud consists of very fine grained carbonate and siliciclastics, largely in the clay and silt size fraction. In the thin sections of embedded mud samples, carbonates make up most of the fine-grained matrix (Fig. 2a and b). Remnants of diatoms and ostracods occur with random orientation. Detrital grains up to fine sand fraction, consisting of quartz, feldspar, mica, chlorite and carbonates, make up as much as $20 \%$ of the sediment. The detrital carbonates are distinguishable from authigenic carbonate phases by their bigger (up to mm measuring) size and fractured shape. The $\mathrm{C}_{\text {org }}$ : $\mathrm{N}_{\text {tot }}$ ratio scatters around 10 (Fig. 3), and plant detritus is evident in thin sections as particles that are opaque, up to several hundred micrometers in size, often elongated and randomly orientated (Fig. 2a and b). These can be identified in the laser scan images due to their chlorophyll-related bright fluorescence (Fig. 4a and b).

Unit II is located between 15 and $22 \mathrm{~cm}$ b.s. and appears as slightly darker, grey-colored mud without macrostructures. The microcrystalline matrix appearance is similar to Unit I; however, phytoclasts and detrital mineral grains are more abundant and up to millimeters in size, whereas the number of bioclasts remains the same. Noticeably, detrital carbonate minerals and quartz grains occur layer-like or in defined lenses (Fig. 2c and d). The component-to-matrix ratio slightly increases up to $25: 75$, and cubic, small (up to $10 \mu \mathrm{m}$ ), opaque minerals often occur intercalated with plant detritus. The $\mathrm{C}_{\text {org }}: \mathrm{N}_{\text {tot }}$ ratio also changes from 10 at $15 \mathrm{~cm}$ to 12 at $22 \mathrm{~cm}$ b.s.

Unit III occurs from 22 to $40 \mathrm{~cm}$ b.s. It is distinctly darker than the units above and shows a significant decrease in water content and porosity to $<50 \mathrm{wt} \%$ and $<0.6$, respectively. This decrease in porosity is also recognizable by a more cohesive sediment texture. Lamination is visible at the core's outer surface but not in the cut section, in which plant detritus noticeably increases. Thin sections of this unit illustrate a rather compacted matrix, a horizontal orientation of elongated phytoclasts and a layered structure with detrital mineral grains (Fig. 2e and f), further supported by the laser scan image (Fig. 4c). Ostracod or diatom fragments still occur but are less abundant than in the units above. The particle-to-matrix ratio increases up to $35: 65$, and the $\mathrm{C}_{\text {org }}: \mathrm{N}_{\text {tot }}$ ratio steadily increases from 12 to 14 through Unit III.

In scanning electron microscope (SEM) images, the matrix appears as microcrystalline aggregate of several nanometer-sized clotted crumbs (Fig. 5). Locally, rhombohedral crystals that are small, up to $1 \mu \mathrm{m}$ in scale and irregularly 

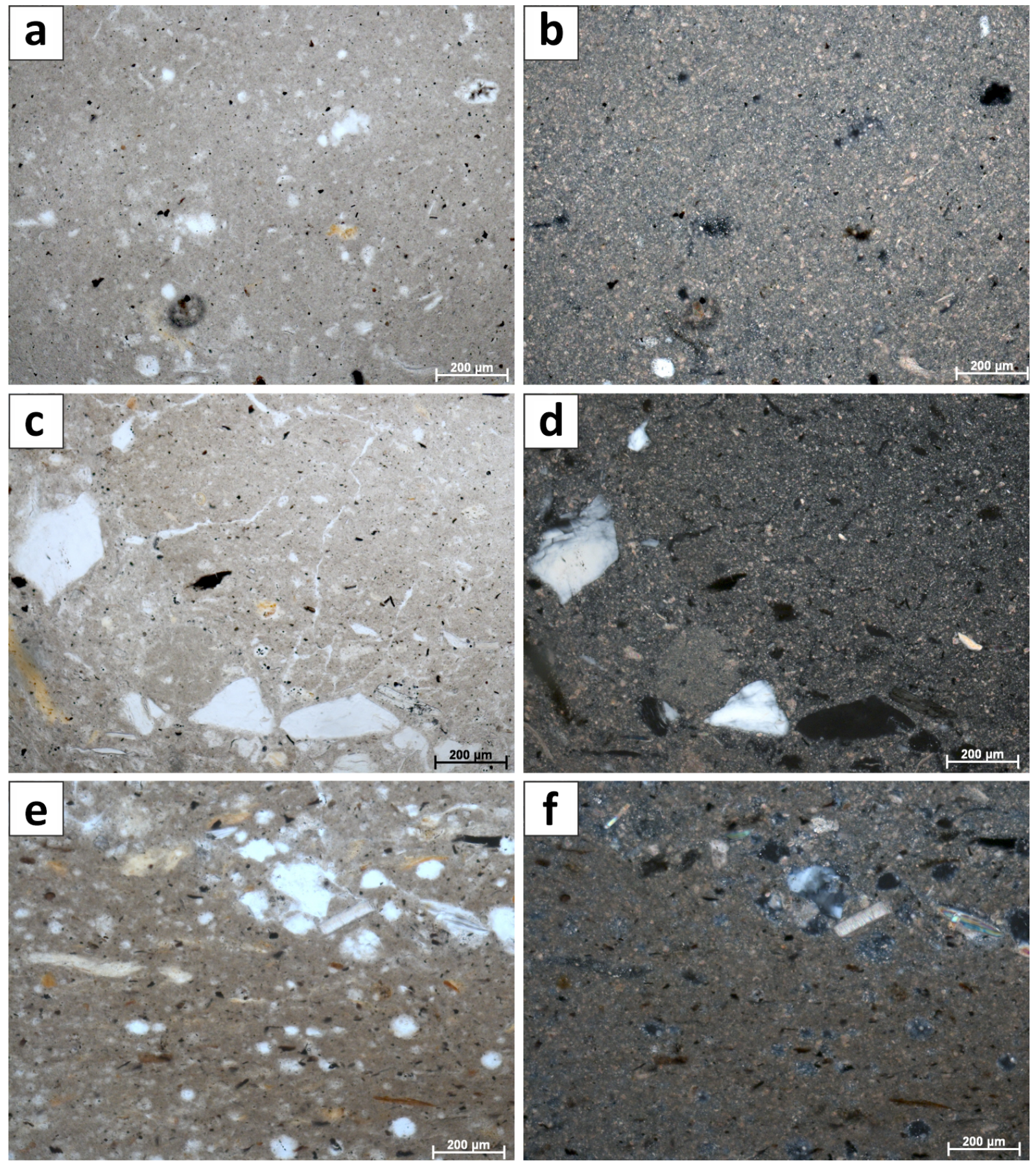

Figure 2. (a) Microfabric of Unit I at $5 \mathrm{~cm}$ depth in transmitted light. Note the randomly oriented, opaque and brownish plant particles. The microcrystalline matrix is more apparent under crossed polars (b). (c) Microfabric overview of Unit II at $17 \mathrm{~cm}$ depth. Large, up-to-fine-sandscale detrital feldspar grains occur in layers. (d) Same image section under crossed polars. (e) Microfabric of Unit III at $28 \mathrm{~cm}$, illustrating the rather compacted shape of the matrix and the elongated appearance of plant detritus. The layering is evident by the occurrence of larger detrital grains in the upper image part. (f) Same section under crossed polars.

shaped are observable. With EDX measurements, these tiny crystals were identified as $\mathrm{Ca}-\mathrm{Mg}$ carbonate phases.

According to the XRD spectra, the bulk sediment mainly consists of carbonates and quartz, with minor contributions of feldspar, clay and mica (Fig. 6). The $d_{104}$ peak shift provides a suitable approach to estimate the $\mathrm{Mg}: \mathrm{Ca}$ ratio in magnesium calcite and dolomite (Lumsden, 1979). Based on the $d_{104}$ peak positions, three carbonate phases 


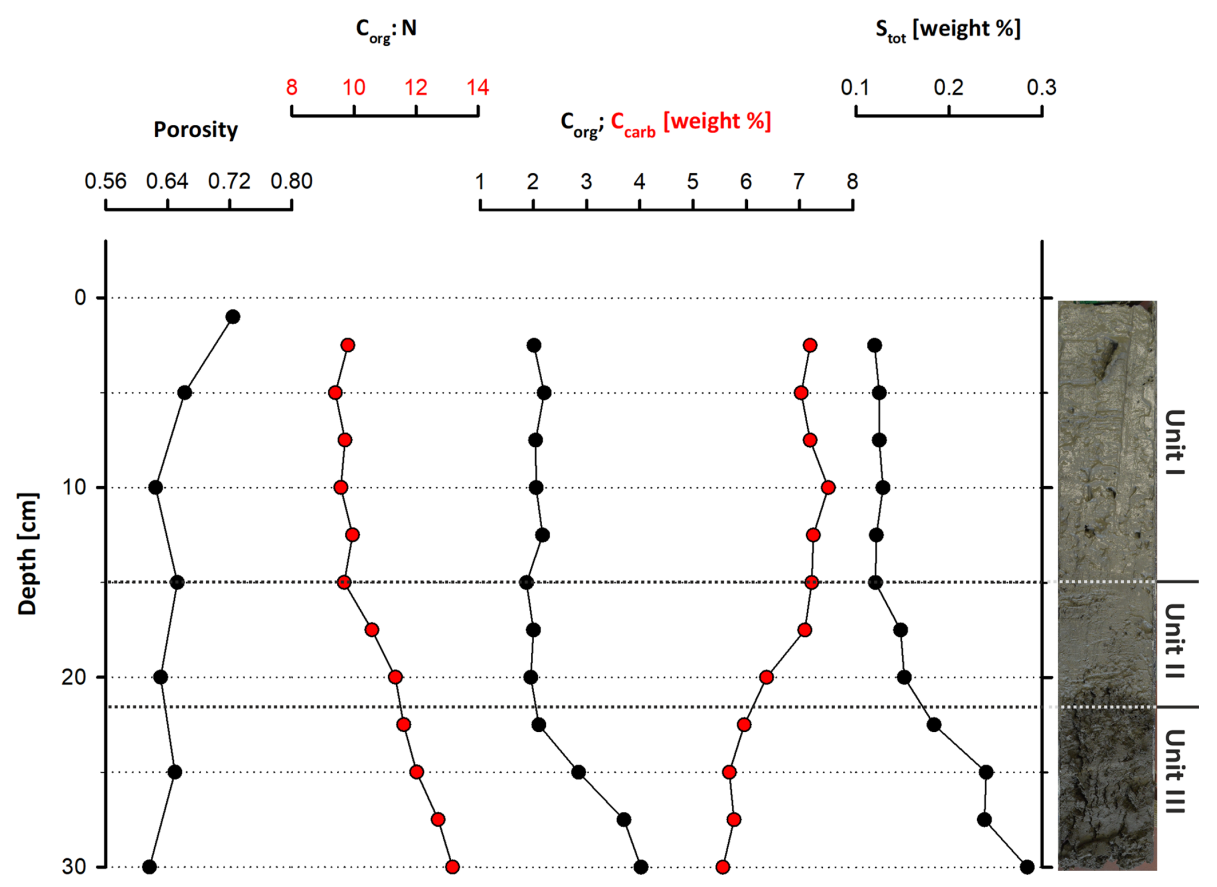

Figure 3. Geochemical parameters through Core LN-K04, showing an increasing amount of organic carbon and total sulfur and a decreasing porosity with depth.

with different $\mathrm{MgCO}_{3}$ content are present: a calcite phase with minor amounts of $\mathrm{MgCO}_{3}$, a high-magnesium-calcite phase (HMC) with circa $18 \mathrm{~mol} \% \mathrm{MgCO}_{3}$ and a very high magnesium-calcium carbonate phase (protodolomite, Fig. 6). The latter shows a 104 peak, shifted from $31^{\circ} 2 \theta$ in ordered dolomite to ca. $30.8^{\circ} 2 \theta$, indicating a $\mathrm{MgCO}_{3}$ content of approx. $45 \mathrm{~mol} \%$. Due to the fact that typical dolomite ordering peaks (i.e., 01.5 and 10.1) could not be identified in the XRD spectra, we informally define the phase as "protodolomite", i.e., a carbonate phase with a nearly $1: 1$ stoichiometry of $\mathrm{Ca}$ and $\mathrm{Mg}$, in which an incipient dolomite structure may or may not be present. Estimated relative mineral abundances vary between the three units (Fig. 7): in Unit I the amount of authigenic carbonate minerals remains relatively constant at $55 \mathrm{wt} \%$, whereas in Unit II a steep and large increase in detrital mineral phases (feldspar, quartz, calcite, mica) can be found. In Unit III the amount of $\mathrm{Ca}-\mathrm{Mg}$ carbonate minerals decreases and scatters around $40 \mathrm{wt} \%$. Mica slightly increases with depth below $23 \mathrm{~cm}$. Nevertheless, the authigenic HMC-to-protodolomite ratio does not change significantly throughout the section. Notably, neither authigenic $\mathrm{Ca}-\mathrm{Mg}$ carbonate phase shows any down-core trend in stoichiometry. $\mathrm{The} \mathrm{Mg} /(\mathrm{Ca}+\mathrm{Mg})$ ratios of distinct solid phases remain largely constant with depth (Fig. 8).

\subsection{Pore water chemistry}

The water chemistry of Lake Neusiedl is characterized by high $\mathrm{pH}$ values (9.02) and moderate salinity $(1.8 \%$ ). Sodium $\left(\mathrm{Na}^{+}\right)$and magnesium $\left(\mathrm{Mg}^{2+}\right)$ are the major cations, with concentrations of 14.3 and $5.1 \mathrm{mmol} \mathrm{L}^{-1}$, respectively. Calcium $\left(\mathrm{Ca}^{2+}\right)$ concentration is considerably lower, at $0.3 \mathrm{mmol} \mathrm{L}^{-1}$. Total alkalinity (TA) measures $11.2 \mathrm{meq} \mathrm{L}^{-1}$, whereas other major anions like chloride $\left(\mathrm{Cl}^{-}\right)$and sulfate $\left(\mathrm{SO}_{4}^{2-}\right)$ hold a concentration of 7 and $4 \mathrm{mmol} \mathrm{L}^{-1}$, respectively. Nutrient $\left(\mathrm{NH}_{4}^{+}, \mathrm{NO}_{2}^{-}, \mathrm{PO}_{4}^{3-}, \Sigma \mathrm{H}_{2} \mathrm{~S}, \mathrm{SiO}_{2(\mathrm{aq})}\right)$ concentrations lie below $0.004 \mathrm{mmol} \mathrm{L}^{-1}$.

The pore water chemistry strongly differs between the sediment and the water column. The $\mathrm{pH}$ drops significantly at the water-sediment interface to a value around 7.5, which stays constant throughout the sediment core (Fig. 9a). The entire section is anoxic, with a redox potential of $-234 \mathrm{mV}$ at the top, which increases to $-121 \mathrm{mV}$ at the bottom (Fig. 9b). $\mathrm{Na}^{+}$and $\mathrm{Cl}^{-}$contents continuously increase with depth, from 14 to 20 and from 7 to $8.8 \mathrm{mmol} \mathrm{L}^{-1}$, respectively (Fig. 9a). $\mathrm{Mg}^{2+}$ and $\mathrm{Ca}^{2+}$ show a different pattern: from 5 to $10 \mathrm{~cm}$ depth, the $\mathrm{Mg}^{2+}$ content decreases from 5 to $4 \mathrm{mmol} \mathrm{L}^{-1}$, whereas the $\mathrm{Ca}^{2+}$ content increases from 0.5 to $0.6 \mathrm{mmol} \mathrm{L}^{-1}$ in the same increment. From $10 \mathrm{~cm}$ downwards, the $\mathrm{Mg}^{2+}$ content scatters around $4 \mathrm{mmolL}^{-1}$ and the $\mathrm{Ca}^{2+}$ content decreases from 0.6 to below $0.5 \mathrm{mmol} \mathrm{L}^{-1}$ (Fig. 9a). Dissolved $\mathrm{SO}_{4}^{2-}$ and hydrogen sulfide $\left(\Sigma \mathrm{H}_{2} \mathrm{~S}\right)$ also show a noticeable trend: the $\Sigma \mathrm{H}_{2} \mathrm{~S}$ content is close to zero in the top $5 \mathrm{~cm}$ of the sediment column, rapidly increases to $1 \mathrm{mmol} \mathrm{L}^{-1}$ between 5 and $10 \mathrm{~cm}$ b.s., and remains constant to the bottom of the section. $\mathrm{SO}_{4}^{2-}$ follows an opposite trend. Its concentration decreases from 4 to $1 \mathrm{mmol} \mathrm{L}^{-1}$ in the upper $10 \mathrm{~cm}$ b.s. and remains constant at $1 \mathrm{mmol} \mathrm{L}^{-1}$ towards the section bottom. Total alkalinity also increases towards the 

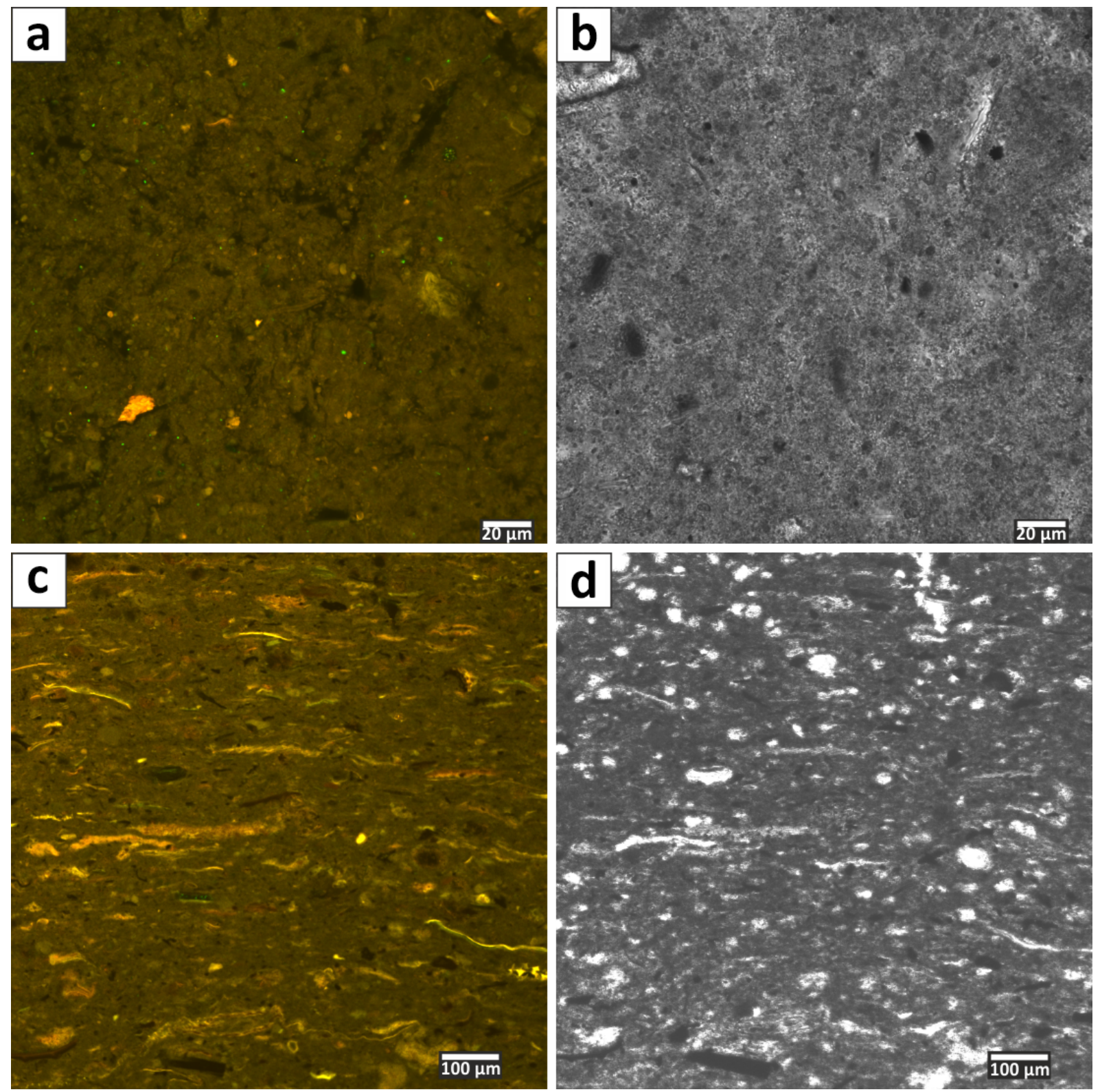

Figure 4. (a) Laser scanning micrograph (excitation $365 \mathrm{~nm}$; emission 397-700 nm) of Unit I microfabric at $2 \mathrm{~cm}$ depth. The small and randomly orientated plant particles show bright fluorescence due to their chlorophyll content. (b) Same section in transmitted light. (c) Fluorescent texture of Unit III (at $28 \mathrm{~cm}$ depth) is visible. The higher amount of plant detritus, particle layering and a compacted matrix are notable. Voids are resin-embedding artifacts. (d) Same section as in (c) but under transmitted light.

lower part of the section, from 11.2 to $16.8 \mathrm{meq} \mathrm{L}^{-1}$, with an increase between 5 and $15 \mathrm{~cm}$ depth.

$\mathrm{NO}_{2}^{-}$is present in the upper $10 \mathrm{~cm}$ of the core and reaches its highest value $\left(0.9 \mu \mathrm{mol} \mathrm{L}{ }^{-1}\right)$ at $2 \mathrm{~cm}$ b.s., while its concentration decreases to zero below $10 \mathrm{~cm}$ b.s. Dissolved iron $\left(\mathrm{Fe}^{2+}\right)$ has a similar trend in the upper $10 \mathrm{~cm}$ b.s., reaching its highest concentration at a depth of $2 \mathrm{~cm}$ $\left(1.4 \mu \mathrm{mol} \mathrm{L}^{-1}\right)$. Below $10 \mathrm{~cm}$ core depth, iron concentrations lie below $0.3 \mu \mathrm{mol} \mathrm{L}-1$, with the exception of an outlier value of $0.5 \mu \mathrm{mol} \mathrm{L}^{-1}$ at $13 \mathrm{cmb}$.s. Concentrations of ammonia
$\left(\mathrm{NH}_{4}^{+}\right)$and phosphate $\left(\mathrm{PO}_{4}^{2-}\right)$ increase with depth. In the uppermost part of the sediment column, they are close to zero and increase to 0.37 and $0.02 \mathrm{mmol} \mathrm{L}^{-1}$ at $13 \mathrm{~cm}$. These values remain constant to the bottom of the core. Dissolved silica shows a curved profile with $0.3 \mathrm{mmol} \mathrm{L}^{-1}$ at the top, reaching a maximum at $15 \mathrm{~cm}$ depth with $0.8 \mathrm{mmol} \mathrm{L}^{-1}$, and declines to concentrations around $0.5 \mathrm{mmol} \mathrm{L}^{-1}$. Methane $\left(\mathrm{CH}_{4}\right)$ concentration also shows a curved trend, reaching its highest value of $227 \mu \mathrm{mol} \mathrm{L}^{-1}$ at a depth of $20 \mathrm{~cm}$ and concentrations between 14 and $64 \mu \mathrm{mol} \mathrm{L}^{-1}$ close to the sedi- 

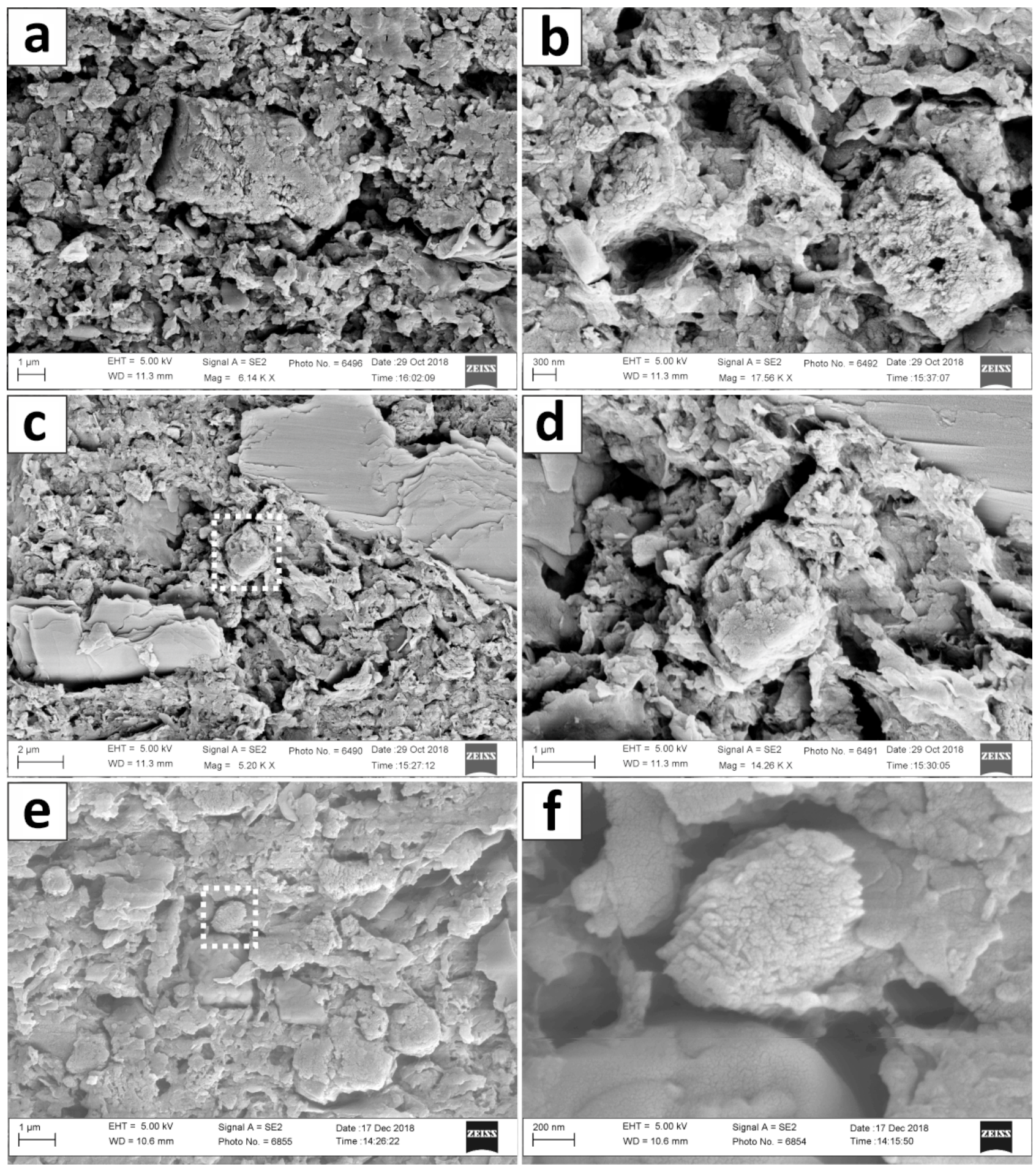

Figure 5. SEM images of Core LN-K 05, showing the crystal morphology of Ca-Mg phases with increasing depth. (a) HMC or protodolomite crystal at $9 \mathrm{~cm}$ depth. (b) Aggregate of $3 \mathrm{HMC}$ or protodolomite crystals at $17 \mathrm{~cm}$ depth. (c) Matrix overview containing microcrystalline crumbs, layered mica crystals and a HMC or protodolomite rhombohedron (indicated by dashed rectangle) at $17 \mathrm{~cm}$ depth. (d) Detail of rhombohedron visible in (c). (e) Matrix overview in $27 \mathrm{~cm}$ depth. HMC and protodolomite carbonate crystals appear rather xenomorphic (indicated by dashed rectangle). (f) Close-up of HMC and protodolomite crystal accentuated in (e). Images produced with a ZEISS Gemini Leo 1530. 

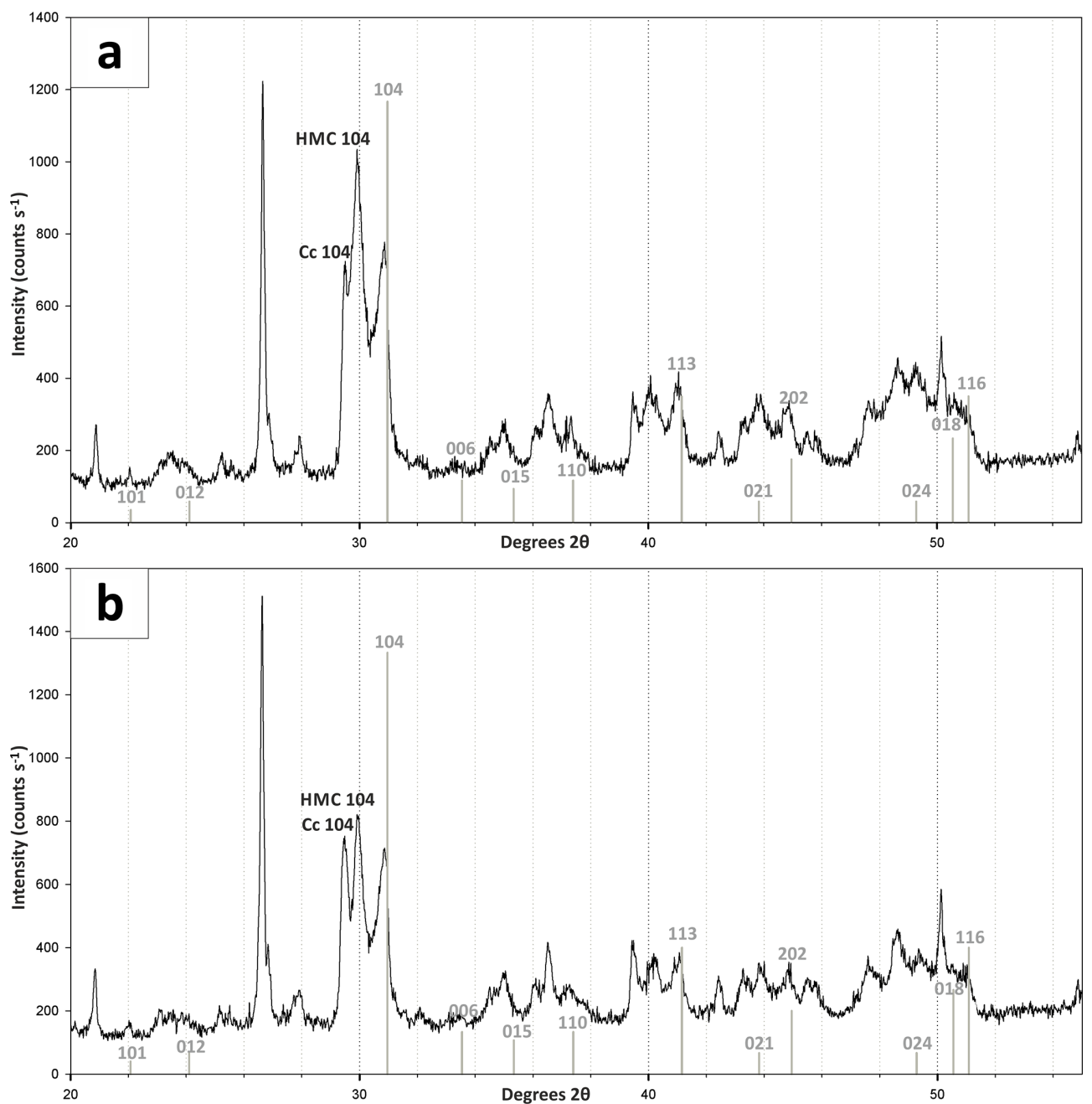

Figure 6. X-ray diffractograms of bulk Lake Neusiedl sediment (a) from $2 \mathrm{~cm}$ and (b) from $27.5 \mathrm{~cm}$ depth. Positions of dolomite peaks are marked in grey. Position of major calcite (Cc 104) and high-magnesium-calcite (HMC 104) peaks are also indicated. Note that typical dolomite ordering peaks could not be identified in the XRD spectra. Furthermore, a figure and a list containing major peaks of identified mineral phases is provided in the Supplement.

ment surface ( 5 and $1 \mathrm{~cm}$, respectively). Dissolved inorganic carbon (DIC) increases from $11.71 \mathrm{mmol} \mathrm{L}^{-1}$ at the top to $18.01 \mathrm{mmol} \mathrm{L}^{-1}$ at $30 \mathrm{~cm}$ depth. Only in the 15 to $20 \mathrm{~cm}$ increment does the amount of DIC slightly decrease, from 15.37 to $14.94 \mathrm{mmol} \mathrm{L}^{-1}$.

According to PHREEQC calculations, the water column at the sampling site (bay of Rust) is supersaturated with respect to aragonite $(\mathrm{SI}=0.92)$, calcite $(\mathrm{SI}=1.07)$, protodolomite $(\mathrm{SI}=2.92)$ and dolomite $(\mathrm{SI}=3.46$; Fig. 10$)$. Sediment pore water is close to equilibrium throughout the whole section with respect to aragonite, whereas calcite is in equilibrium to slightly supersaturated between 10 and $27.5 \mathrm{~cm}$ depth. Protodolomite reaches equilibrium between 2.5 and $5 \mathrm{~cm}$, while dolomite is supersaturated in the entire section. It should be noted that all saturation graphs reveal parallel trends, with their highest saturation at $17.5 \mathrm{~cm}$ and their lowest at $2.5 \mathrm{~cm}$ depth.

\subsection{Bacterial community composition}

Bacterial 16S rRNA gene analysis revealed the presence of a diverse bacterial community, with 1226 amplicon sequence variants (ASVs) clustered at $100 \%$ sequence identity within the water column, 2085 to $2467 \mathrm{ASVs}$ in the top $20 \mathrm{~cm}$ of the sediment core and 1417 to 1581 ASVs in the deeper sediment $(20-35 \mathrm{~cm}$ core depth). The different bacterial taxa were grouped by known metabolic properties of characterized relatives, listed in Whitman (2015) and additional literature (see Supplement). The distribution of the most abundant bacterial taxa differs between the water column and the sediment (Fig. 11a and b).

The water column is dominated by aerobic heterotrophs, mainly Alphaproteobacteria and Actinobacteria, which are only of minor abundance in the sediment. Among the Alphaproteobacteria, the SAR11 clade capable of oxidizing C1 


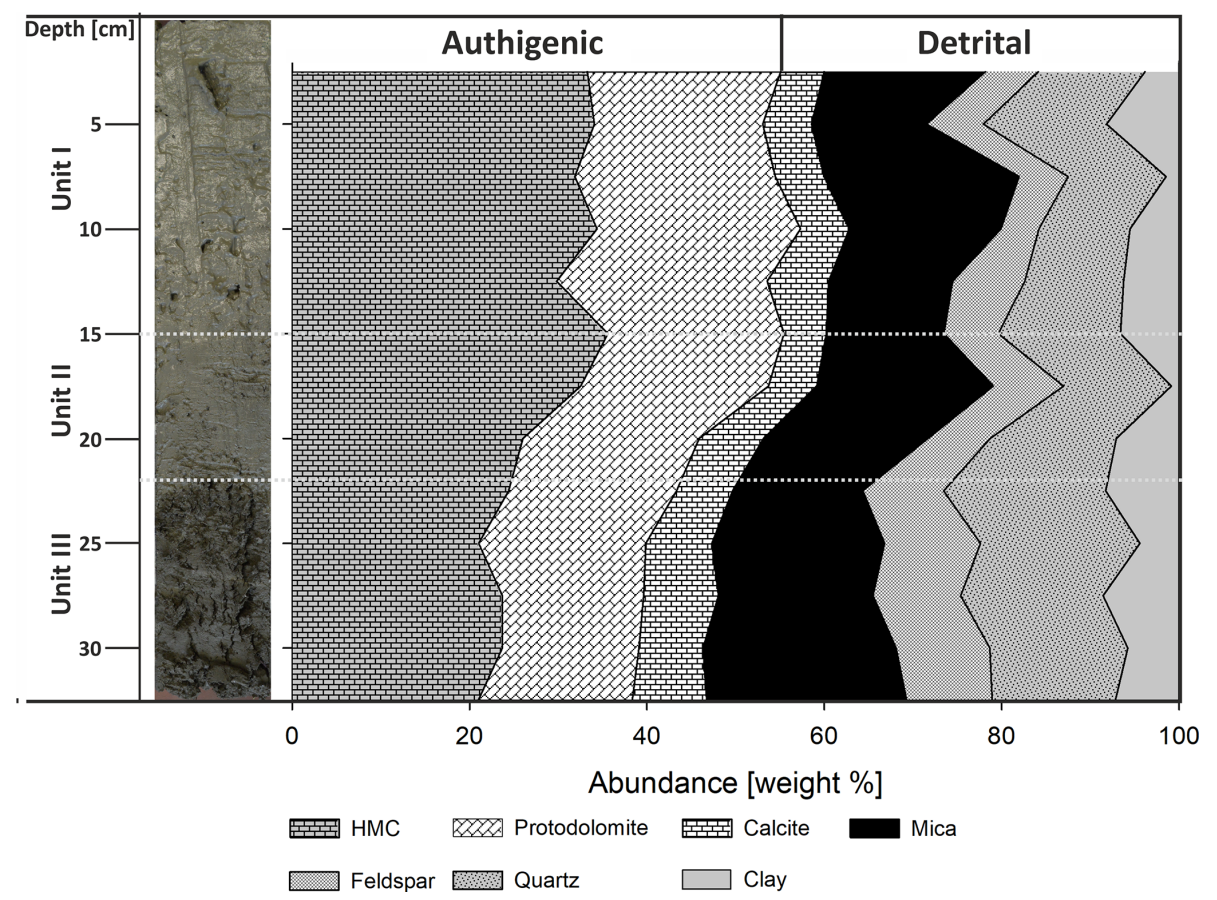

Figure 7. Core LN-K04 with the defined units I-III (left) and mineral quantities estimated from main peak heights (right; HMC: highmagnesium calcite). The changes of mineral abundances coincide with unit boundaries.

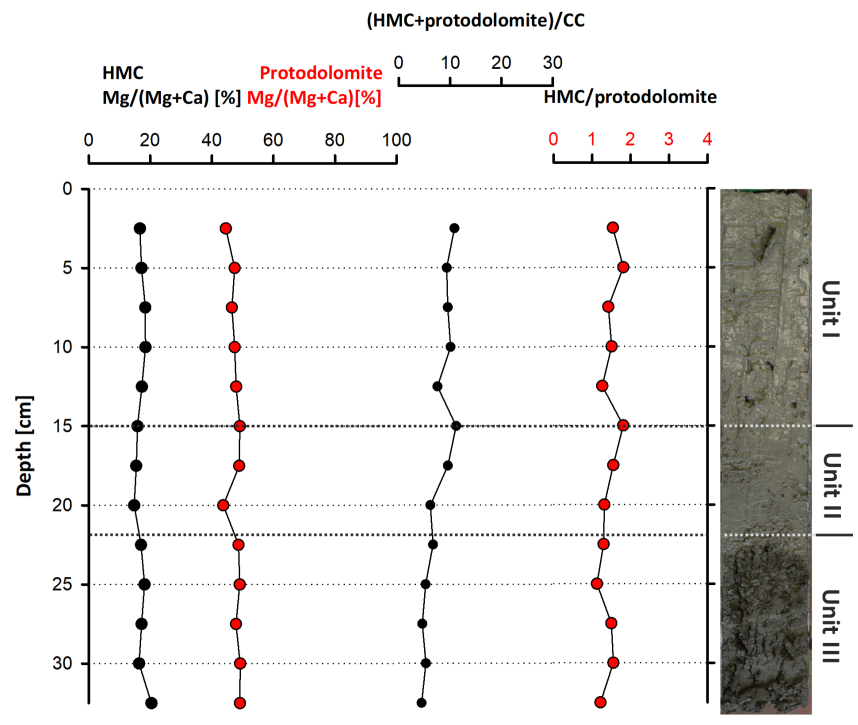

Figure 8. Stoichiometric compositions of authigenic carbonate phases (HMC and protodolomite), their abundance ratio and their relation to detrital calcite.

compounds (Sun et al., 2011) is predominant. The nitrogenfixing Frankiales are the most abundant representatives of the Actinobacteria. Furthermore, coccoid cyanobacteria (Synechococcales) and Bacteroidetes are present in high relative abundances in the water column.
Within sediment Unit I (0-15 cm b.s.), the bacterial community composition changes to mainly anaerobic and facultatively anaerobic taxa. Only the uppermost $5 \mathrm{~cm}$ shows increased relative abundances of cyanobacteria (Synechococcales) and Bacteroidetes (aerobes and facultative anaerobes; Alderkamp et al., 2006; Flombaum et al., 2013) as well as Verrucomicrobia (mostly aerobic and facultative anaerobic heterotrophs; He et al., 2017), which include nitrogen-fixing members (Chiang et al., 2018). Besides these groups, Gammaproteobacteria, Acidobacteria, Chloroflexi and sulfate-reducing Deltaproteobacteria are abundant. Deltaproteobacteria mainly consist of Desulfobacteraceae and Desulfarculales (Fig. 11c and d).

In sediment Unit II $(15-22 \mathrm{~cm}$ b.s. $)$, the relative proportions of these groups show a transition between sediment unit I and III. While Gammaproteobacteria, Acidobacteria and Deltaproteobacteria are still abundant, the relative abundance of Chloroflexi increases strongly from $24.29 \%$ to $35.43 \%$. Within the SRB, Desulfobacteraceae and Desulfarculales are successively replaced by Deltaproteobacteria of the Sva0485 clade. The Syntrophobacterales show their maximum relative abundance within sediment Unit II.

In sediment Unit III $(22-40 \mathrm{~cm}$ b.s. $)$, the abundance of Chloroflexi further increases to form the dominant bacterial phylum. The phylum consists of Dehalococcoidia and Anaerolineae. Other abundant groups in this unit are Acidobacteria, Gammaproteobacteria and Deltaproteobacteria of the Sva0485 clade. Further details of the microbial com- 

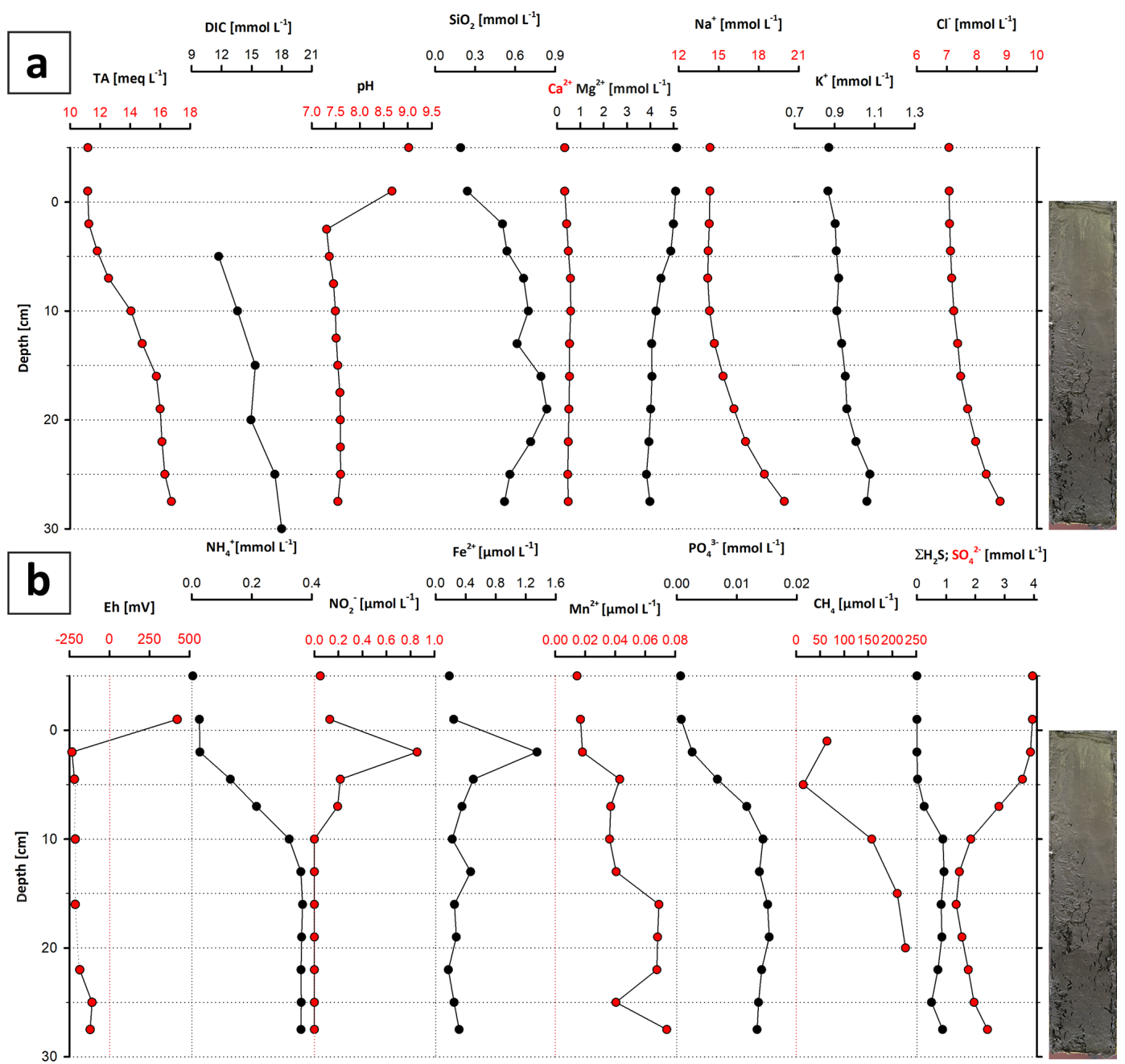

Figure 9. Major ion (a) and metabolite concentrations (b) in the pore water of core LN-K03. Note that the sample slightly above $0 \mathrm{~cm}$ depth represents the supernatant water, and the top data points represent the water column (see text for explanations).

munity composition are given in von Hoyningen-Huene et al. (2019).

\section{Discussion}

\subsection{Pore water gradients and their effect on $\mathrm{Ca}-\mathrm{Mg}$ carbonate supersaturation}

Concentrations of the conservative trending ions $\mathrm{Na}^{+}, \mathrm{K}^{+}$ and $\mathrm{Cl}^{-}$steadily increase towards the bottom of the core section, reaching 19,1 and $9 \mathrm{mmol} \mathrm{L}^{-1}$, respectively. These concentrations are considerably higher than in the water column, where these ions measure 14, 0.9 and $7 \mathrm{mmol} \mathrm{L}^{-1}$. Moreover, $\mathrm{SO}_{4}^{2-}$ shows an increase near the bottom of the core and is reported to further increase to values of $6.5 \mathrm{mmol} \mathrm{L}^{-1}$ in a longer section from a different locality in the bay of Rust (not shown in this study), which is higher than the overlying lake water $\left(3.9 \mathrm{mmol} \mathrm{L}^{-1}\right)$. This rise in ion concentration indicates an ion source below the sampled interval. While saline deep ground waters are known to be present in deep aquifers (Neuhuber, 1971; Blohm, 1974; Wolfram, 2006), it is also possible that more highly concentrated brine exists in deeper mud layers due to more recent evaporation events (Fig. 12). Lake Neusiedl dried out entirely between 1865 and 1875 (Moser, 1866), and high ion concentrations may relate to thin evaporite layers and brine that formed during this event.

The cause of the exceptionally high $\mathrm{Mg}$ : Ca ratio, which reaches values around 15 in the water column, is not yet entirely understood. The low $\mathrm{Ca}^{2+}$ concentrations in Lake Neusiedl can be linked to calcium carbonate formation (e.g., Wolfram and Herzig, 2013), but the high amounts of $\mathrm{Mg}^{2+}$ ions and their source remain elusive. Boros et al. (2014) describe similar phenomena in small alkaline lakes of the western Carpathian plain and relate the high magnesium levels to 


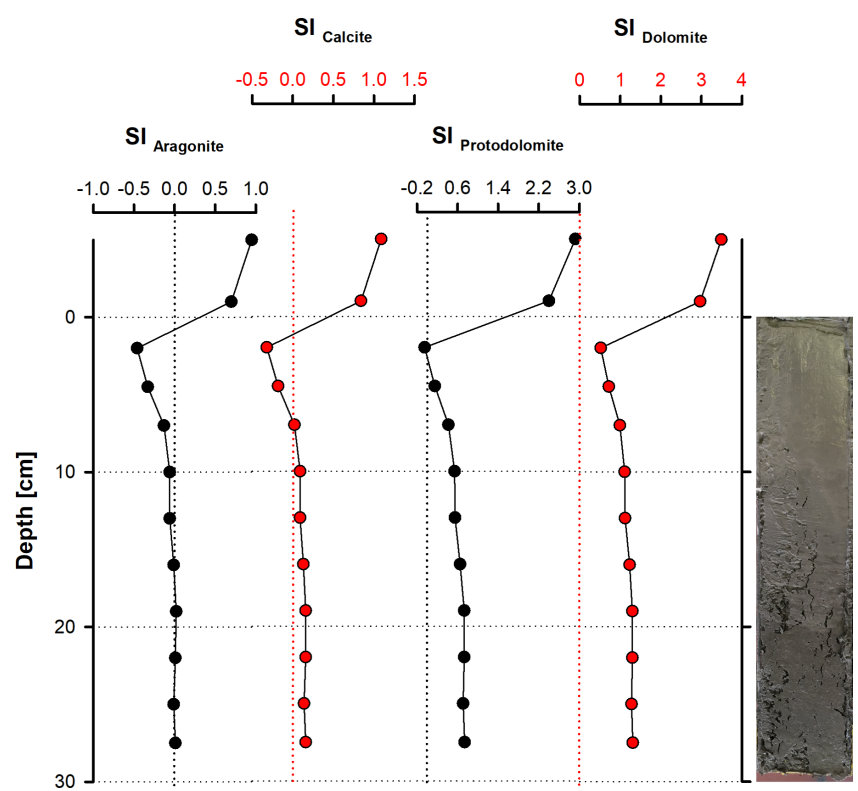

Figure 10. Saturation indices (SIs) of selected carbonate mineral phases. It can be noted that all phases are clearly supersaturated in the water column but close to saturation throughout most of the sediment column (except for the uppermost $10 \mathrm{~cm}$ ).

local hydrogeological conditions and the geological substrate of the lakes.

It should be noted that the $\mathrm{Mg}$ : Ca ratio reaches values around 7 in the $5-10 \mathrm{~cm}$ increment of the pore water section. This is caused by a considerable decrease in the $\mathrm{Mg}^{2+}$ ions in this increment (from 5 to $4 \mathrm{mmol} \mathrm{L}^{-1}$ ) and an increase in $\mathrm{Ca}^{2+}$ concentration (from 0.3 to $0.5 \mathrm{mmol} \mathrm{L}^{-1}$ ). This effect can be partly explained by a transition zone between lake and pore water in this section, in which the concentration gradient is balanced. Other factors contributing to this concentration shift may include ion exchange, e.g., with $\mathrm{NH}_{4}^{+}$generated in the pore water at clay minerals (von Breymann et al., 1990; Celik et al., 2001). However, in the case of Lake Neusiedl, the $\mathrm{NH}_{4}^{+}$concentration is not sufficient to explain this change within the $\mathrm{Mg}$ : Ca ratio. Another factor causing the decrease in $\mathrm{Mg}^{2+}$ concentrations may be the supply of dissolved silica for the precipitation of clay mineral precursor phases (Birsoy, 2002). Increasing $\mathrm{SiO}_{2}$ concentration with depth indicates the dissolution of diatom frustules, which have been observed in thin sections of the present study. It is not entirely clear if this $\mathrm{SiO}_{2}$ release into the pore water is related to hydrochemical or biogenic parameters. As the $\mathrm{SiO}_{2}$ increase in the upper $20 \mathrm{~cm}$ of the pore water neither clearly correlates with alkalinity nor with the salinity gradients (concentrations of conservative ions), and $\mathrm{pH}$ is not predictive (Ryves et al., 2006), diatom dissolution by an evident chemical undersaturation (saturation indices of amorphous $\mathrm{SiO}_{2}$ lie between -1.35 and -0.65 ) may be not the only driver for the $\mathrm{SiO}_{2}$ release. It is also conceivable that the enhanced silica release in the pore water is caused by bacteria, which attack the organic matrix of diatom frustules and, thus, expose the silica-bearing skeletons to chemical undersaturation (Bidle and Azam, 1999). Bidle et al. (2003) have linked enhanced dissolution potential to uncultured Gammaproteobacteria. This phylum showed increased abundances in the upper sediment column, supporting the hypothesis of a biogenic contribution to diatom dissolution and, hence, the provision of $\mathrm{SiO}_{2}$ to sequester $\mathrm{Mg}^{2+}$ (Fig. 12; Eq. 5) in Lake Neusiedl's pore waters.

\subsection{Microbial activity and carbonate saturation}

Microbial metabolic reactions strongly affect pore water chemistry, particularly $\mathrm{pH}$, alkalinity and hence carbonate mineral saturation state. In the present approach, the assessment of bacterial community composition is based on the metagenomic DNA within the sediment. This contains the active bacterial communities at their current depth as well as deposited, dormant or dead cells that originated in the water column or at shallower sediment depth (More et al., 2019). In the present study, a background of dormant or dead cells is evident through ASVs belonging to strict aerobes (e.g., Rhizobiales, Gaiellales) that were detected within deeper parts of the anaerobic mud core (Figs. 11, 12 and 13; Supplement Table S5).

The water column is characterized by aerobic heterotrophs, including $\mathrm{C} 1$ oxidizers (SAR11 clade of the Alphaproteobacteria) and highly abundant freshwater Actinobacteria. These are common in most freshwater environments. An impact on carbonate mineral saturation or nucleation, however, is unknown, as their role in the biogeochemical cycles remains largely undescribed (Neuenschwander, et al., 2018). A high abundance of cyanobacteria of the Synechococcales is present in the water column. Synechococcales are known to create favorable conditions for carbonate nucleation in alkaline environments by raising the $\mathrm{pH}$, photosynthetic metabolism and the complexation of cations at their cell envelopes (Thompson and Ferris, 1990). Further research is required to verify their potential role in HMC or protodolomite formation in Lake Neusiedl.

In sediment Unit I ( $0-15 \mathrm{~cm}$ b.s.) Synechococcales as well as aerobic Bacteroidetes are still abundant in the top $5 \mathrm{~cm}$, likely due to the sedimentation of their cells from the water column. The uppermost measurement at $2.5 \mathrm{~cm}$ depth revealed reducing conditions and a low, close-to-neutral $\mathrm{pH}$. This supports heterotrophic metabolisms and fermentation by Gammaproteobacteria, Acidobacteria, Chloroflexi and Deltaproteobacteria, which are the major taxa at this depth. At the very top of the sediment, a peak in $\mathrm{NO}_{2}^{-}$and $\mathrm{Fe}^{2+}$ points to nitrate reduction and $\mathrm{Fe}^{3+}$ reduction (Kotlar et al., 1996; Jørgensen and Kasten, 2006). Farther below, the successive increase in $\mathrm{NH}_{4}^{+}$and $\mathrm{PO}_{4}^{3-}$ reflects anaerobic bacterial decomposition of organics, consistent, for example, with 


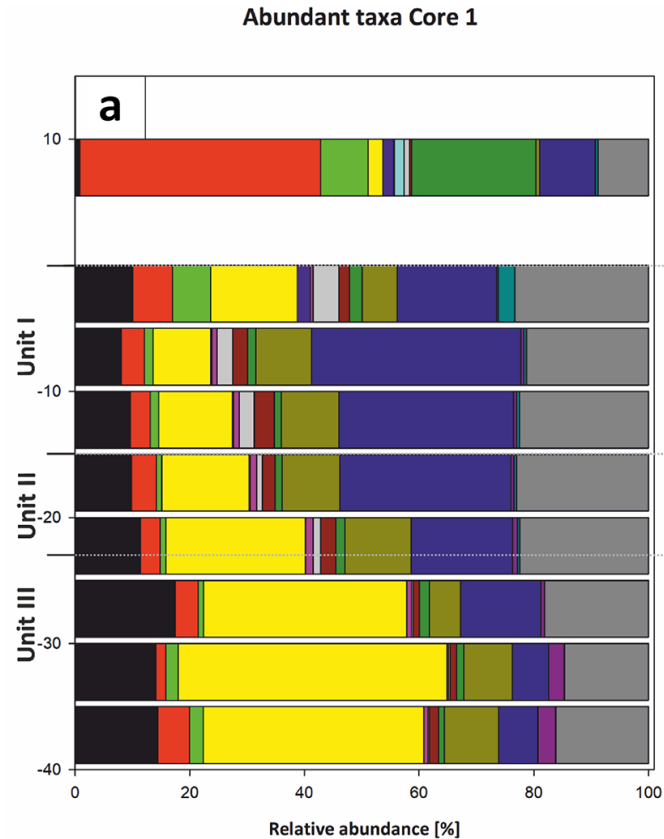

Sulfate-reducing bacteria Core 1

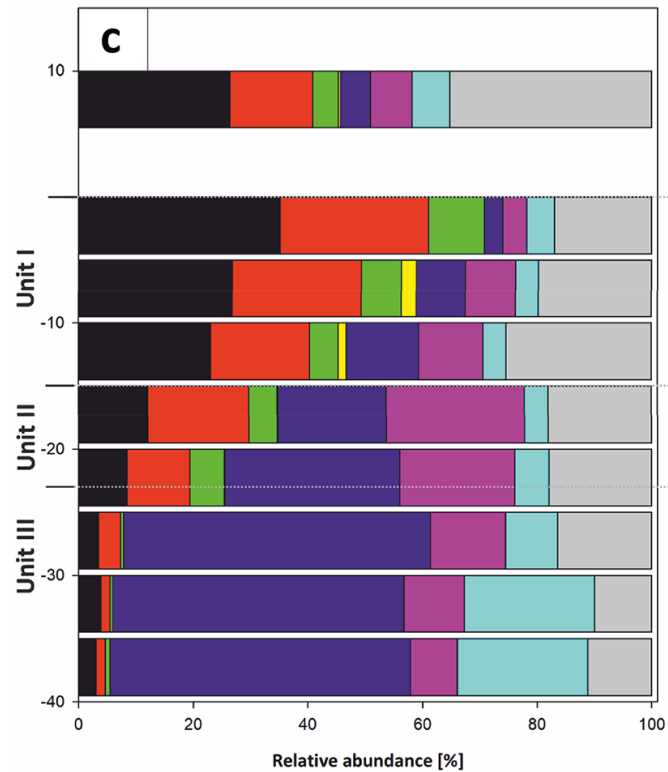

Abundant taxa Core 2

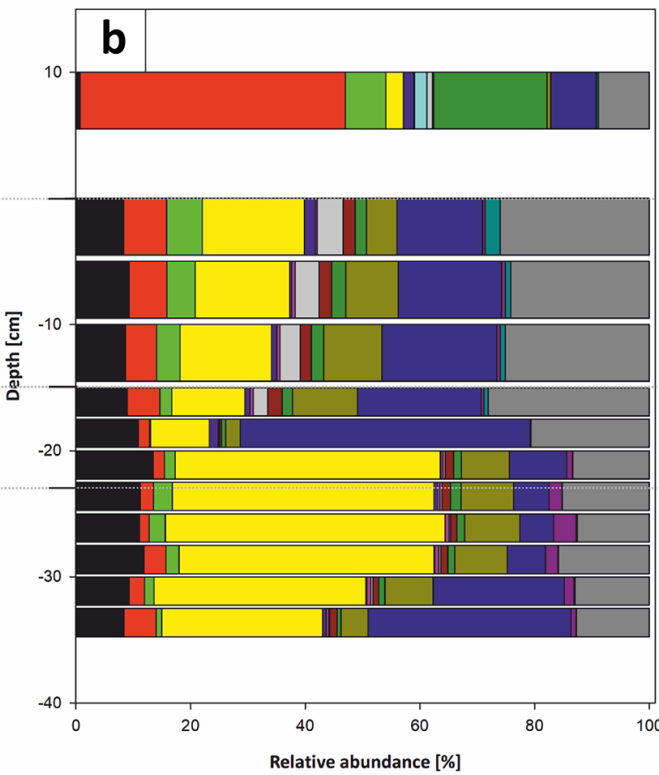

Sulfate-reducing bacteria Core 2

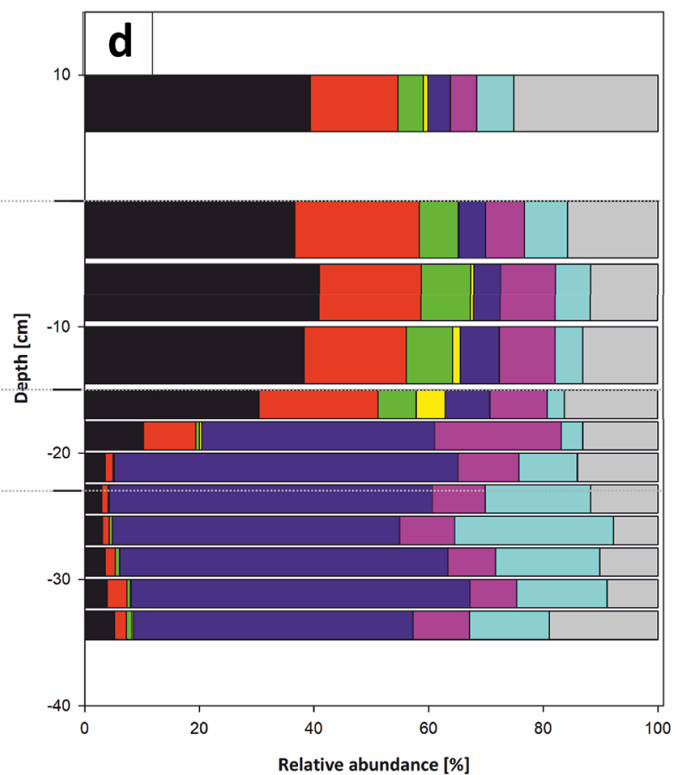

Acidobacteria Actinobacteria $\square$ Bacteriodetes $\square$ Chloroflexi Cyanobacteria $\square$ Firmicutes-Clostridia $\square$ Firmicutes-Erysipelotrichia $\square$ Gemmatimonadetes Nitrospirae Proteobacteria-alpha $\square$ Proteobacteria-delta Proteobacteria-gamma Spirochaetes $\square$ Verrucomicrobiae $\square$ Rare taxa $(<0.5 \%)$

Figure 11. Most abundant taxa in Core 1 (a) and Core 2 (b). The legend indicates all abundant taxa on the phylum level, including the class level for Proteobacteria and Firmicutes. All orders below $0.5 \%$ relative abundance were summarized as rare taxa. The abundant taxa change at the transitions from water column to sediment and the lithological units (I-III). The taxonomic composition of sulfate reducers in Core 1 (c) and Core 2 (d) changes gradually from Unit I-II and more pronouncedly from Unit II-III. Sulfate reducers are shown on the class and order level. The column thickness relates to the sampled increments of either 5 or $2.5 \mathrm{~cm}$. Sulfate reducers represent up to $15 \%$ of the total bacterial community and were normalized to $100 \%$ relative abundance to illustrate the changes within their composition.

Chloroflexi capable of dissimilatory nitrate reduction to ammonium (DNRA).

Sulfate reducers are present in Unit I. Their increasing relative abundance coincides with a decrease in $\mathrm{SO}_{4}^{2-}$ and an increase in $\Sigma \mathrm{H}_{2} \mathrm{~S}$ (Fig. 9). Despite a concomitant increase in alkalinity, the bulk metabolic effect of the microbial community keeps the $\mathrm{pH}$ and carbonate saturation low (Fig. 12; Eq. 7). Model calculations in aquatic sediments have shown that sulfate reduction initially lowers the $\mathrm{pH}$ (e.g., Soetart et al., 2007), and as the alkalinity increases, the $\mathrm{pH}$ converges 


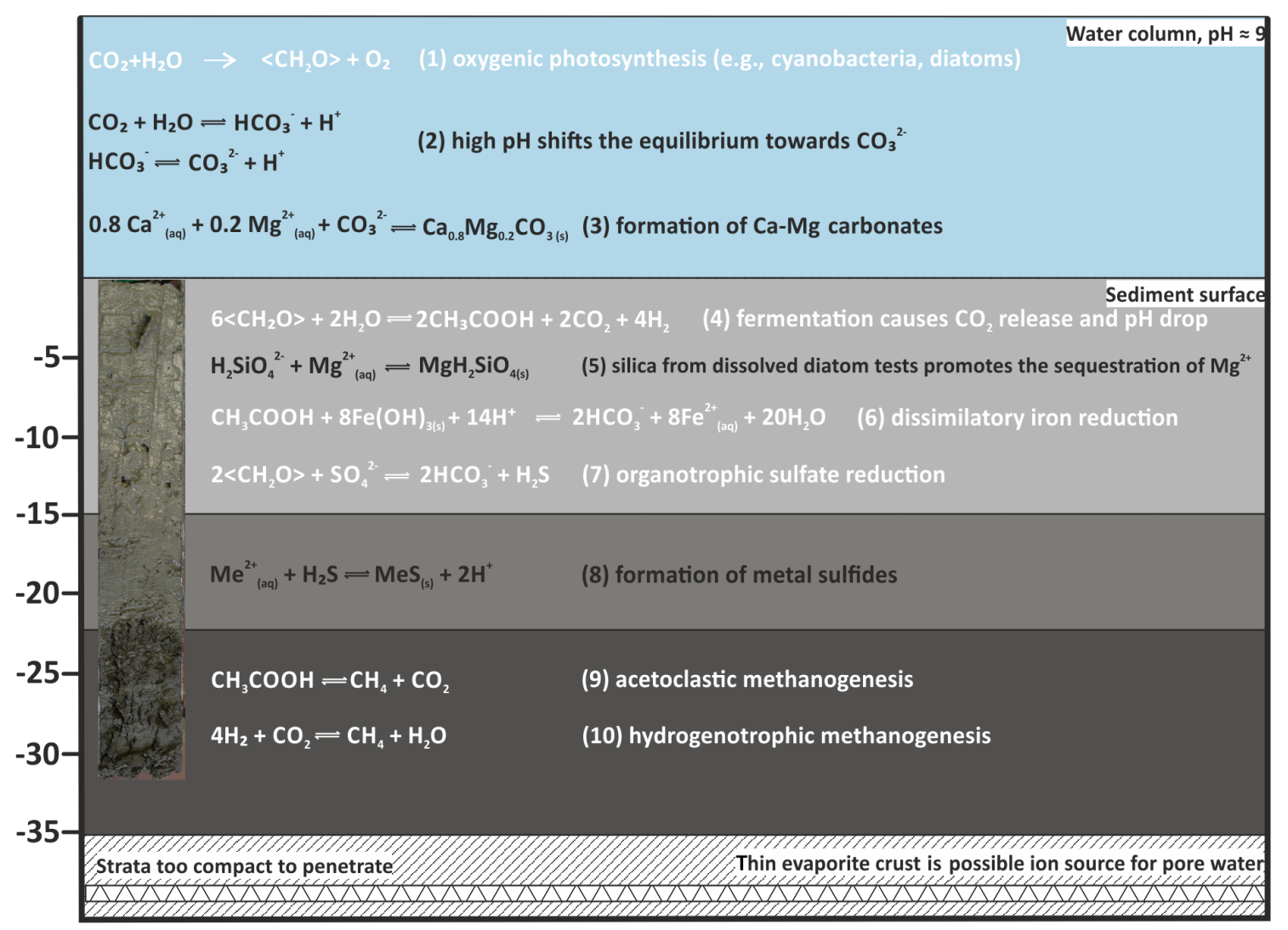

Figure 12. Suggested major microbial (simplified, indicated in white) and geochemical processes in water and sediment column of Lake Neusiedl.

at values between 6 and 7. As a consequence, the saturation index for carbonate minerals concomitantly drops. If a sufficient amount of sulfate is reduced $\left(>10 \mathrm{mmol} \mathrm{L}^{-1}\right)$, the saturation level recovers and may slightly surpass initial conditions (Meister, 2013). Only when sulfate reduction is coupled to anaerobic oxidation of methane (AOM) would the effect of both raise the $\mathrm{pH}$ to higher values. However, as methane occurs below $10 \mathrm{~cm}$ (Fig. 10), where $\mathrm{SO}_{4}^{2-}$ is still present, $\mathrm{AOM}$ is incomplete or absent.

In sediment Unit II $(15-22 \mathrm{~cm}$ b.s.) and Unit III (22$40 \mathrm{~cm}$ b.s.), the bacterial community composition shifts towards a high abundance of Chloroflexi (Dehalococcoidia and Anaerolineae), known for their involvement in carbon cycling as organohalide respirers and hydrocarbon degraders (Hug et al., 2013). This change may reflect an increase in poorly degradable organic electron donors and hence plant debris in the laminated core Unit III. The change in the relative composition of different orders within the SRB (i.e., change from Desulfobacterales and Desulfarculales to Sva0485 and Spirochaetales) may also be related to a change in available organic substrates. In total, sulfate reduction remains high, also recognizable by the occurrence of opaque (sulfide) mineral spots and the increase in $\mathrm{S}_{\mathrm{tot}}$ in the lower part of the section (Figs. 2e, 3). Fermentation and sulfate re- duction remain high with increasing depth, indicated by the near-neutral $\mathrm{pH}$ and raised alkalinity at low carbonate mineral saturation.

\subsection{Time and depth of carbonate formation}

A significant difference in saturation state between the water column and the sediment is evident. Whilst the water column is supersaturated with respect to aragonite, HMC, protodolomite and dolomite, they are close to equilibrium in the pore water. The downward shift of saturation from the water column to the pore water is to be expected due to the onset of anaerobic, heterotrophic metabolic activity (Fig. 12; Eq. 4).

The absence of aragonite at Lake Neusiedl is not entirely clear, as its formation is commonly linked to an interplay between high temperature, mineral supersaturation and $\mathrm{Mg}: \mathrm{Ca}$ ratios (Fernández-Díaz et al., 1996; Given and Wilkinson, 1985). Based on precipitation experiments by De ChoudensSanchez and Gonzalez (2009), which include temperatures of $19.98^{\circ} \mathrm{C}$ and $\mathrm{Mg}$ : Ca ratios up to 5, aragonite would be the favored phase in Lake Neusiedl, as the lake's Mg : Ca ratio of 15 is too high and the concomitant calcite saturation not sufficient to provide calcite growth. However, the mentioned experiments were performed in a precipitation chamber with 
degassing conditions and hence reduced $\rho \mathrm{CO}_{2}$, which makes them incomparable to the present study. In contrast, Niedermayr et al. (2013) observed the preferential formation of calcite at high $\mathrm{Mg}$ : Ca ratios when an amino acid (polyaspartic acid) is present. As the water column bears numerous bacterial species (Fig. 11) and potentially comparable organic compounds, this is a likely scenario for Lake Neusiedl. Nevertheless, the precise evaluation of why aragonite is not present is impossible, as no related analytical data from the water column are available.

According to Löffler (1979), magnesium calcite forms first, which is then altered into protodolomite. The alteration takes place from the inside, hence resulting in a protodolomite core and a HMC rim. However, the observation that ratios of $\mathrm{HMC}$ to protodolomite remain constant around $40 \%$ to $50 \%$ indicates no significant diagenetic alteration in the uppermost $30 \mathrm{~cm}$ of the sediment. Abrupt changes in these ratios, along with changing contributions of detrital mineral phases, such as mica and quartz, rather suggest changing sedimentation. Likewise, (low-Mg) calcite essentially depends on the input of ostracod shells and transport of detrital carbonates delivered from the catchment area. Furthermore, no significant diagenetic overprint in the form of recrystallization and/or cementation is apparent from the applied light- and electron-optical methods as well as the geochemical gradients. Most importantly, the stoichiometric ratio of each carbonate phase remains constant, confirming that no large-scale recrystallization of these phases occurs.

Considering that no signs of carbonate precipitation or diagenetic alteration were observed in the sediment column from the bay of Rust, it can be concluded that carbonate minerals are unlikely to form in the pore water. Instead $\mathrm{Ca}-$ $\mathrm{Mg}$ carbonate crystals may precipitate in the water column and are deposited at the bottom of the lake (Fig. 12; Eq. 3). Age estimations for the mud sediments range from 150 years (Löffler, 1979) to 850-2300 years before present (radiocarbon ages from Neuhuber et al., 2015). Our dataset indicates that authigenic $\mathrm{Ca}-\mathrm{Mg}$ carbonate does not necessarily form in its present location, which is consistent with the large discrepancy between sediment and authigenic carbonate age.

The observed detrital mineral spectrum reflects the mineral composition of the adjacent Leitha (mica, feldspar, quartz, calcite) and Rust hills (calcite), and minerals are either windblown or transported by small, eastbound tributaries (Löffler, 1979). The layering in the lower part of the section (Unit III) reflects the lack of homogenization by wind-driven wave action and indicates a higher water level. As this unit also contains higher amounts of plant particles and siliciclastics, possibly due to a higher water influx from vegetated surroundings, it is conceivable that the deposition of Unit III reflects environmental conditions before the installation of the water level regulating the Einser canal in 1909. The increase in $\mathrm{C}_{\text {org }}$ with depth further reflects this depositional change. This fits the increasing number of plant particles with depth. The lignin-bearing plant particles are difficult to degrade for heterotrophic organisms under the prevailing anoxic conditions (Benner et al., 1984). The higher amounts of plant material may reflect a lower salinity and thus higher primary production at their time of deposition, which can also be related to the stronger water level oscillations before regulations, including a larger lake surface and a catchment area that is almost a magnitude higher (refer to a map in the Supplement, provided by Hegedüs, 1783). Based on this consideration one might concur with the sediment age estimation of circa 150 years, as proposed by Löffler (1979). Nevertheless, it is important to distinguish between actual mineral formation and sediment deposition, including relocation: an unpublished sediment thickness map (GeNeSee project; unpublished) suggests a current-driven relocation of mud deposits in the southwestern lake area, where the bay of Rust is located. Thus, the radiocarbon data from Neuhuber et al. (2015) possibly reflect the date of precipitation, whereas Löffler's age estimation may refer to the date of local mud deposition.

\subsection{Potential pathways of authigenic Ca-Mg carbonate formation}

The precise formation pathway of authigenic $\mathrm{Ca}-\mathrm{Mg}$ carbonate mineral precipitation in Lake Neusiedl has been controversially discussed. Some authors suggest a precipitation of HMC in the water column and subsequent alteration to protodolomite or dolomite within the anoxic pore water of the sediment (Müller et al., 1972). Others suggest the direct formation of protodolomite in the water column (Schiemer and Weisser, 1972). Our XRD and geochemical data support the latter hypothesis, as no diagenetic alteration is retraceable throughout the sediment section. While low saturation or even undersaturation in the sediment precludes a microbially induced precipitation in the pore water, high supersaturation in the surface water body would support precipitation in the water column. Given the high alkalinity, $\mathrm{CO}_{2}$ uptake by primary producers may have contributed to the high $\mathrm{pH}$ and high supersaturation in the surface water.

An alternative explanation to the controversially discussed microbial dolomite formation would be the ripening under fluctuating $\mathrm{pH}$ conditions in the water column. Deelman (1999) has demonstrated in his precipitation experiments that dolomite forms if the $\mathrm{pH}$ varies. At times of strong supersaturation, metastable carbonates (protodolomite) are formed, which ripen to ordered dolomite during subsequent phases of undersaturation of the metastable carbonate (while the stable phase remains supersaturated). This observation reflects Ostwald's step rule, according to which the metastable phase always forms first. Ostwald's step rule can also be demonstrated in the pore water, which is buffered by the metastable phase. Thereby the formation of the stable phase (dolomite) is inhibited despite its supersaturation. This observation is comparable with Land's (1998) "failure" 
Oxygen requirements of bacteria Core 1

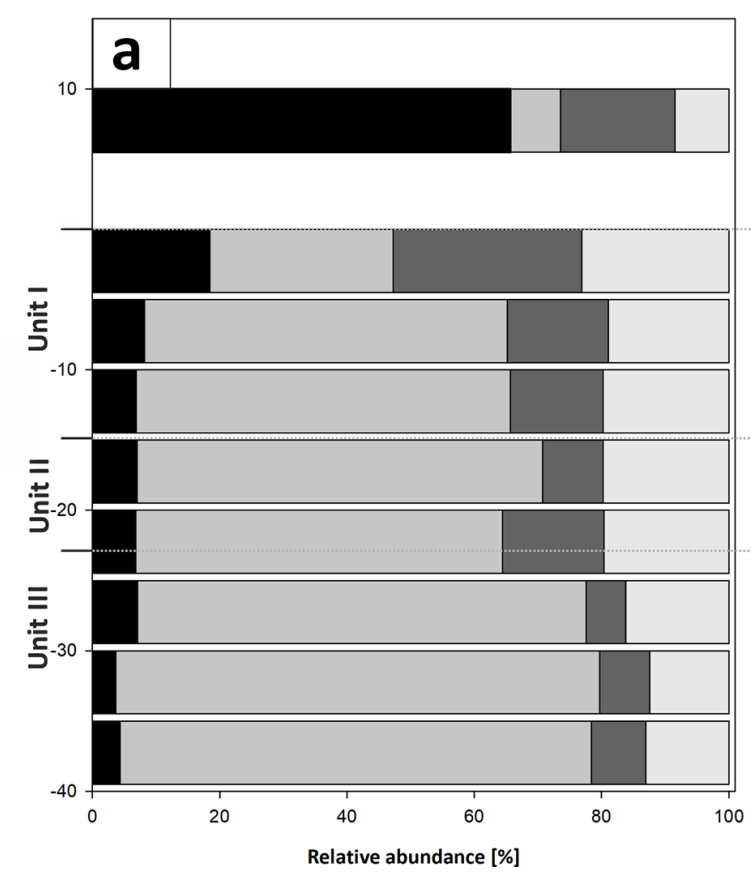

Oxygen requirements of bacteria Core 2

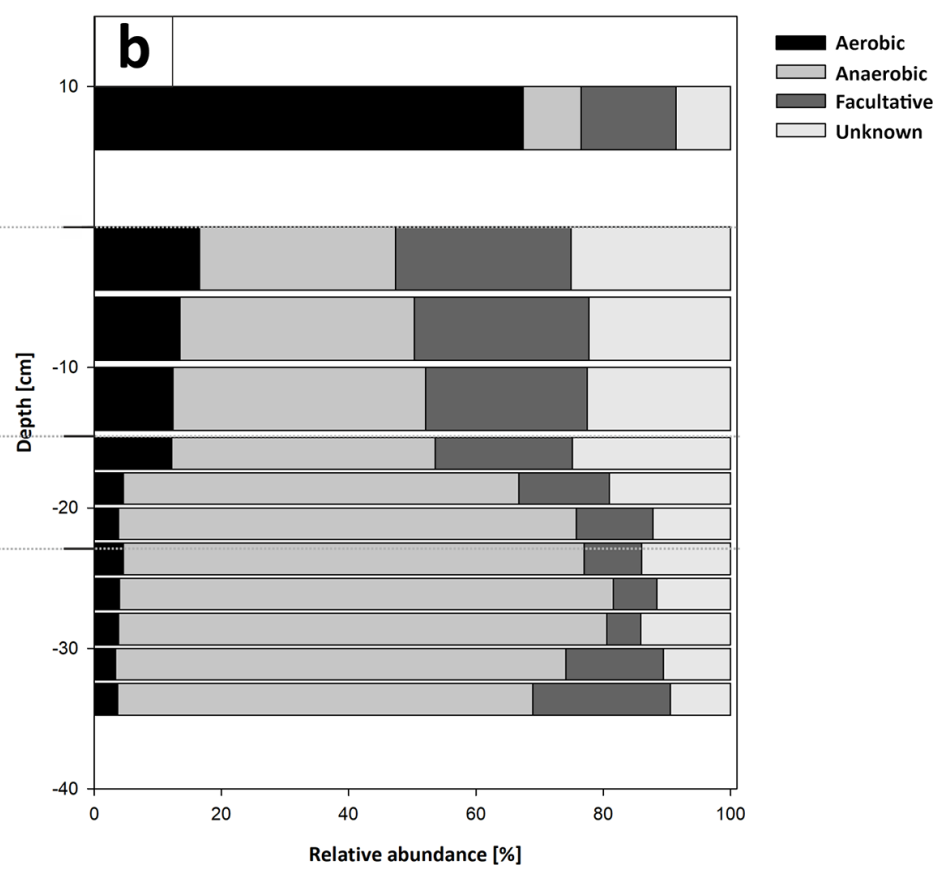

Figure 13. Oxygen utilization within the most abundant members of the bacterial community (a) and the potential energy metabolisms (b) plotted versus depth in Cores 1 and 2. The community in the water column indicates a predominantly aerobic regime. Rare taxa $(<0.5 \%$ relative abundance) were removed from the analysis, and abundances were normalized to $100 \%$. Bacteria with an unknown metabolism were grouped as unknowns. The community inhabiting the sediment shows an early onset of sulfate reduction in the upper sediment layers and a shift to fermentation at the transition from Unit II to III.

to form dolomite for 30 years despite 1000-fold supersaturation.

In Lake Neusiedl, fluctuation of the $\mathrm{pH}$ in the overlying water column is likely to occur due to variations in meteoric water input and temperature, which may cause episodes of undersaturation. This is a fact which is supported by Wolfram and Herzig (2013), who report an increase in $\mathrm{Ca}^{2+}$ concentration, depending on a dissolution of Ca carbonates in Lake Neusiedl's open water during the winter months, when water levels rise and temperatures decrease. Such a seasonally dependent formation mechanism has recently been suggested to explain dolomite formation in a Triassic evaporative tidal flat setting (Meister and Frisia, 2019). Alternatively, Moreira et al. (2004) proposed that undersaturation of metastable phases occurs as a result of sulfide oxidation near the sediment surface. While we traced only small abundances of sulfate-oxidizing bacteria near the sediment-water interface (1\%), fluctuating hydrochemical conditions are likely to occur in the diffusive boundary layer, where a $\mathrm{pH}$ drop is observed as a result of the biogeochemical processes discussed above. Dolomite formation in the diffusive boundary layer has been observed in Lake Van (McCormack et al., 2018) and was interpreted as a result of abundant microbial EPS, linked to a changing water level and hence chemistry. In Lake Neusiedl, the amount of EPS in the diffusive boundary layer is difficult to estimate, but the potential $\mathrm{Ca}-\mathrm{Mg}$ carbonate favoring change in hydrochemistry is granted.

\section{Conclusions}

Two phases of $\mathrm{Ca}-\mathrm{Mg}$ carbonates (HMC, protodolomite) as well as calcite occur in the form of fine-grained mud in Lake Neusiedl. Bacterial metabolic activity, including sulfate reduction and fermentation, leads to a decrease in $\mathrm{pH}$ within the sediment, leaving the $\mathrm{Ca}-\mathrm{Mg}$ carbonate phases at low or minor saturation in the pore water. In contrast, $\mathrm{Ca}-$ $\mathrm{Mg}$ carbonate phases are highly supersaturated in the alkaline water column. There, the carbonate formation mechanism may involve fluctuating hydrochemical conditions, leading to periods of undersaturation and ripening of HMC to protodolomite. Further, carbonate precipitation may be supported by phototrophic uptake of $\mathrm{CO}_{2}$ by cyanobacteria, e.g., by Synechococcus. Precipitation of $\mathrm{Ca}-\mathrm{Mg}$ carbonate, thus, most likely occurs in the open water. Based on the presented dataset, precipitation or diagenetic alteration within the sediment is not indicated. The precise $\mathrm{Ca}-\mathrm{Mg}$ carbonate reaction pathway needs further evaluation. 
Data availability. All data required for the presented plots and Supplement and analytical data were submitted to PANGEA (Data Publisher for Earth and Environmental Science) and are accessible via https://doi.org/10.1594/PANGAEA.909663 (Fussmann et al., 2019). Paired-end raw reads of the $16 \mathrm{~S}$ rRNA gene dataset are described in and accessible via von Hoyningen-Huene et al. (2019).

Supplement. The supplement related to this article is available online at: https://doi.org/10.5194/bg-17-2085-2020-supplement.

Author contributions. DF, HB, AM, RP and AR investigated, formally analyzed and curated the hydro- and geochemical data. AJEvHH investigated the bacterial communities and formally analyzed and curated the data together with DS and DF. DF wrote the original draft, which was reviewed and edited by PM, AJEvHH, AR, DS, GA and RD. GA, RD and PM conceptualized the study, acquired the funding, and administered and supervised the project.

Competing interests. The authors declare that they have no conflict of interest.

Acknowledgements. We thank Wolfgang Dröse, Birgit Röring and Axel Hackmann for their support during lab work. Furthermore, we thank Susanne Gier for support during XRD measurements and Beatrix Bethke, Caroline Haberhauer and Barbara Hofbauer for help during sampling. We also thank Erich Draganits, Regina and Rudolf Krachler, and Stephanie Neuhuber for insightful discussions. Anja Poehlein and Melanie Heinemann are acknowledged for performing the sequencing and initial sequence processing.

Financial support. This research has been supported by the German Research Foundation (DFG), research unit FOR-1644 "CHARON" (subproject TP7: grant nos. AR 335/8-1 and DA 374/11-1), by the European Commission (Marie Skłodowska-Curie IEF Project TRIADOL; grant no. 626025), and by the Department of Geodynamics and Sedimentology at the University of Vienna.

Review statement. This paper was edited by Aninda Mazumdar and reviewed by two anonymous referees.

\section{References}

Alderkamp, A.-C., Nejstgaard, J. C., Verity, P. G., Zirbel, M. J., Sazhin, A. F., and van Rijssel, M.: Dynamics in carbohydrate composition of Phaeocystis pouchetii colonies during spring blooms in mesocosms, J. Sea Res., 55, 169-181, https://doi.org/10.1016/j.seares.2005.10.005, 2006.

Bácsatyai, L., Csaplovics, E., Márkus, I., and Sindhuber, A.: Digitale Geländemodelle des Neusiedler See-Beckens, Wissenschaftliche Arbeiten aus dem Burgenland, 97, 1-53, 1997.
Balci, N., Menekşe, M., Karagüler, N. G., Şeref Sönmez, M., and Meister, P.: Reproducing authigenic carbonate precipitation in the hypersaline Lake Ac1 göl (Turkey) with microbial cultures, Geomicrobiol. J., 33, 758-773, https://doi.org/10.1080/01490451.2015.1099763, 2016.

Benner, R., Maccubbin, A., and Hodson, R. E.: Anaerobic biodegradation of the lignin and polysaccharide components of lignocellulose and synthetic lignin by sediment microflora, Appl. Environ. Microbiol., 47, 998-1004, 1984.

Bidle, K. D. and Azam, F.: Accelerated dissolution of diatom silica by marine bacterial assemblages, Nature, 397, 508-512, https://doi.org/10.1038/17351, 1999.

Bidle, K. D., Brzezinski, M. A., Long, R. A., Jones, J. L., and Azam, F.: Diminished efficiency in the oceanic silica pump caused by bacteria-mediated silica dissolution, Limnol. Oceanogr., 48 , 1855-1868, https://doi.org/10.4319/lo.2003.48.5.1855, 2003.

Birgel, D., Meister, P., Lundberg, R., Horath, T. D., Bontognali, T. R., Bahniuk, A. M., de Rezende, C. E., Vásconcelos, C., and McKenzie, J. A.: Methanogenesis produces strong ${ }^{13} \mathrm{C}$ enrichment in stromatolites of Lagoa Salgada, Brazil: a modern analogue for Palaeo-/Neoproterozoic stromatolites?, Geobiology, 13, 245-266, https://doi.org/10.1111/gbi.12130, 2015.

Birsoy, R.: Formation of sepiolite-palygorskite and related minerals from solution, Clay. Clay Miner., 50, 736-745, https://doi.org/10.1346/000986002762090263, 2002.

Blohm, M.: Sedimentpetrographische Untersuchungen am Neusiedler See, Österreich, Dissertation, Ruprecht-KarlUniversität Heidelberg, 1-85, 1974.

Bontognali, T. R., Vasconcelos, C., Warthmann, R. J., Bernasconi, S. M., Dupraz, C., Strohmenger, C. J., and McKenzie, J. A.: Dolomite formation within microbial mats in the coastal sabkha of Abu Dhabi (United Arab Emirates), Sedimentology, 57, 824844, https://doi.org/10.1111/j.1365-3091.2009.01121.x, 2010.

Bontognali, T. R., McKenzie, J. A., Warthmann, R. J., and Vasconcelos, C.: Microbially influenced formation of Mg-calcite and Ca-dolomite in the presence of exopolymeric substances produced by sulphate-reducing bacteria, Terra Nova, 26, 72-77, https://doi.org/10.1111/ter.12072, 2014.

Boros, E., Horváth, Z., Wolfram, G., and Vörös, L.: Salinity and ionic composition of the shallow astatic soda pans in the Carpathian Basin, Int. J. Limnol., 50, 59-69, https://doi.org/10.1051/limn/2013068, 2014.

Brady, P.V., Krumhansl, J. L., and Papenguth, H. W.: Surface complexation clues to dolomite growth, Geochem. Cosmochem. Ac., 60, 727-731, https://doi.org/10.1016/0016-7037(95)00436$\mathrm{x}, 1996$.

Callahan, B. J., McMurdie, P. J., and Holmes, S. P.: Exact sequence variants should replace operational taxonomic units in marker-gene data analysis, ISME J., 11, 2639-2643, https://doi.org/10.1038/ismej.2017.119, 2017.

Celik, M., Özdemir, B., Turan, M., Koyuncu, I., Atesok, G., and Sarikaya, H.: Removal of ammonia by natural clay minerals using fixed and fluidised bed column reactors, Water Sci. Technol., 1, 81-88, https://doi.org/10.2166/ws.2001.0010, 2001.

Chen, S., Zhou, Y., Chen, Y., and Gu, J.: fastp: an ultra-fast all-in-one FASTQ preprocessor, Bioinformatics, 34, i884-i890, https://doi.org/10.1093/bioinformatics/bty560, 2018.

Chiang, E., Schmidt, M. L., Berry, M. A., Biddanda, B. A., Burtner, A., Johengen, T. H., Palladino, D., and Denef, V. J.: Verrucomi- 
crobia are prevalent in north-temperate freshwater lakes and display class-level preferences between lake habitats, PLoS One, 13, e0195112, https://doi.org/10.1371/journal.pone.0195112, 2018.

Court, W. M., Paul, A., and Lokier, S. W.: The preservation potential of environmentally diagnostic sedimentary structures from a coastal sabkha, Mar. Geol., 386, 1-18, https://doi.org/10.1016/j.margeo.2017.02.003, 2017.

De Choudens-Sanchez, V. and Gonzalez, L. A.: Calcite and aragonite precipitation under controlled instantaneous supersaturation: elucidating the role of $\mathrm{CaCO}_{3}$ saturation state and $\mathrm{Mg} / \mathrm{Ca}$ ration on calcium carbonate polymorphism, J. Sediment. Res., 79, 363376, https://doi.org/10.2110/jsr.2009.043, 2009.

Deelman, J.: Low-temperature nucleation of magnesite and dolomite, Neues Jb. Miner. Monat., 7, 289-302, 1999.

Deng, S., Dong, H., Lv, G., Jiang, H., Yu, B., and Bishop, M. E.: Microbial dolomite precipitation using sulfate reducing and halophilic bacteria: Results from Qinghai Lake, Tibetan Plateau, NW China, Chem. Geol., 278, 151-159, https://doi.org/10.1016/j.chemgeo.2010.09.008, 2010.

Fernandez-Diaz, L., Putnis, A., Prieto, M., and Putnis, C. $\mathrm{V}$. : The role of magnesium in the crystallization of calcite and aragonite in a porous medium, J. Sed. Res., 66, 482-491, https://doi.org/10.1306/d4268388-2b26-11d7$8648000102 \mathrm{c} 1865 \mathrm{~d}, 1996$.

Flombaum, P., Gallegos, J. L., Gordillo, R. A., Rincón, J., Zabala, L. L., Jiao, N., Karl, D. M., Li, W. K., Lomas, M. W., and Veneziano, D.: Present and future global distributions of the marine Cyanobacteria Prochlorococcus and Synechococcus, P. Natl. Acad. Sci. USA, 110, 9824-9829, https://doi.org/10.1073/pnas.1307701110, 2013.

Frisia, S., Borsato, A., and Hellstrom, J.: High spatial resolution investigation of nucleation, growth and early diagenesis in speleothems as exemplar for sedimentary carbonates, Earth-Sci. Rev., 178, 68-91, https://doi.org/10.1016/j.earscirev.2018.01.014, 2018.

Fussmann, D., von Hoyningen-Huene, A., Reimer, A., Schneider, D., Maier, A., Peticzka, R., Babkova, H., Arp, G., Rolf, D., and Meister, P.: Analytical Data Lake Neusiedl, PANGAEA, https://doi.org/10.1594/PANGAEA.909663, 2019.

Given, R. K. and Wilkinson, B. H.: Kinetic control of morphology, composition, and mineralogy of abiotic sedimentary carbonates, J. Sed. Res., 55, 109-119, https://doi.org/10.1306/212f862a2b24-11d7-8648000102c1865d, 1985.

Grasshoff, K., Kremling, K., and Ehrhardt, M.: Methods of seawater analysis, John Wiley \& Sons, 91-251, https://doi.org/10.1002/9783527613984, 2009.

Gregg, J. M., Bish, D. L., Kaczmarek, S. E., and Machel, H. G.: Mineralogy, nucleation and growth of dolomite in the laboratory and sedimentary environment: a review, Sedimentology, 62, 1749-1769, https://doi.org/10.1111/sed.12202, 2015.

He, S., Stevens, S. L., Chan, L.-K., Bertilsson, S., del Rio, T. G., Tringe, S. G., Malmstrom, R. R., and McMahon, K. D.: Ecophysiology of freshwater Verrucomicrobia inferred from metagenome-assembled genomes, mSphere, 2, e00277-17, https://doi.org/10.1128/msphere.00277-17, 2017.

Hegedüs, J. N.: Lake Neusiedl and Hansag: Universal map of the County of Sopron, State archive of Sopron, 1783.
Herrmann, P., Pascher, G., and Pistonik, J.: Geologische Karte der Republik Österreich. Geologische Bundesanstalt, Wien, 1993.

Herzig, A.: Der Neusiedler See - Limnologie eines Steppensees, Denisia 33, zugleich Kataloge des oberösterreichischen Landesmuseums, 163, 101-114, 2014.

Herzig, A. and Dokulil, M.: Neusiedler See - ein Steppensee in Europa, in: Ökologie und Schutz von Seen, edited by: Dokulil, M., Hamm, A., and Kohl, J.-G., Facultas-Universitäts-Verlag, Wien, 401-415, 2001.

Horváth, F.: Towards a mechanical model for the formation of the Pannonian basin, Tectonophysics, 226, 333-357, https://doi.org/10.1016/0040-1951(93)90126-5, 1993.

Hug, L. A., Castelle, C. J., Wrighton, K. C., Thomas, B. C., Sharon, I., Frischkorn, K. R., Williams, K. H., Tringe, S. G., and Banfield, J. F.: Community genomic analyses constrain the distribution of metabolic traits across the Chloroflexi phylum and indicate roles in sediment carbon cycling, Microbiome, 1, 22, https://doi.org/10.1186/2049-2618-1-22, 2013.

Illing, L., Wells, A., and Taylor, J.: Penecontemporary dolomite in the Persian Gulp, SEPM Special Publication, 13, 89-111, 1965.

Jørgensen, B. B. and Kasten, S.: Sulfur cycling and methane oxidation, in: Marine Geochemistry, edited by: Schulz, H. D. and Zabel, M., Springer, Berlin, 271-309, https://doi.org/10.1007/3540-32144-6_8, 2006.

Klindworth, A., Pruesse, E., Schweer, T., Peplies, J., Quast, C., Horn, M., and Glöckner, F. O.: Evaluation of general 16S ribosomal RNA gene PCR primers for classical and next-generation sequencing-based diversity studies, Nucl. Acid. Res., 41, e1, https://doi.org/10.1093/nar/gks808, 2013.

Kotlar, E., Tartakovsky, B., Argaman, Y., and Sheintuch, M.: The nature of interaction between immobilized nitrification and denitrification bacteria, J. Biotechnol., 51, 251-258, https://doi.org/10.1016/s0168-1656(96)01603-3, 1996.

Krachler, R., Korner, I., Dvorak, M., Milazowszky, N., Rabitsch, W., Werba, F., Zulka, P., and Kirschner, A.: Die Salzlacken des Seewinkels: Erhebung des aktuellen ökologischen Zustandes sowie Entwicklung individueller Lackenerhaltungskonzepte für die Salzlacken des Seewinkels (2008-2011), Österreichischer Naturschutzbund, Eisenstadt, Österreich, 2012.

Krachler, R., Krachler, R., Gülce, F., Keppler, B. K., and Wallner, G.: Uranium concentrations in sediment pore waters of Lake Neusiedl, Austria, Sci. Total Environ., 633, 981-988, https://doi.org/10.1016/j.scitotenv.2018.03.259, 2018.

Land, L. S.: Failure to Precipitate Dolomite at ${ }^{25} \mathrm{C}$ from dilute solution despite 1000-fold oversaturation after 32 years, Aquat. Geochem., 4, 361-368, 1998.

Lippmann, F.: The System $\mathrm{CaCO}_{3}-\mathrm{MgCO}_{3}$, in: Sedimentary Carbonate Minerals, edited by: Lippmann, F., Springer, Berlin, 148190, https://doi.org/10.1007/978-3-642-65474-9_4, 1973.

Liu, D., Xu, Y., Papineau, D., Yu, N., Fan, Q., Qiu, X., and Wang, H.: Experimental evidence for abiotic formation of low-temperature proto-dolomite facilitated by clay minerals, Geochim. Cosmochim. Ac., 247, 83-95, https://doi.org/10.1016/j.gca.2018.12.036, 2019.

Löffler, H.: Neusiedlersee: The limnology of a shallow lake in central europe, in: Monographiae Biologicae, 37, edited by: Junk, W., bv Publishers, The Hague, 543 pp., https://doi.org/10.1007/978-94-009-9168-2, 1979. 
Loisl, J., Tari, G., Draganits, E., Zámolyi, A., and Gjerazi, I.: Highresolution seismic reflection data acquisition and interpretation, Lake Neusiedl, Austria, northwest Pannonian Basin, Interpretation, 6, SB77-SB974, https://doi.org/10.1190/int-2017-0086.1, 2018.

Lutterotti, L., Bortolotti, M., Ischia, G., Lonardelli, I., and Wenk, H.: Rietveld texture analysis from diffraction images, Z. Kristallogr., Supplements, 26, 125-130, https://doi.org/10.1524/zksu.2007.2007.suppl_26.125, 2007.

Machel, H. G.: Concepts and models of dolomitization: a critical reappraisal, Geol. Soc. Lond. Spec. Publ. 235, 7-63, https://doi.org/10.1144/gsl.sp.2004.235.01.02, 2004.

Martin, M.: Cutadapt removes adapter sequences from highthroughput sequencing reads, EMBnet J., 17, 10-12, https://doi.org/10.14806/ej.17.1.200, 2011.

McCormack, J., Bontognali, T. R., Immenhauser, A., and Kwiecien, O.: Controls on cyclic formation of Quaternary early diagenetic dolomite, Geophys. Res. Lett., 45, 3625-3634, https://doi.org/10.1002/2018gl077344, 2018.

Meister, P.: Two opposing effects of sulfate reduction on carbonate precipitation in normal marine, hypersaline, and alkaline environments, Geology, 41, 499-502, https://doi.org/10.1130/g34185.1, 2013.

Meister, P. and Frisia, S.: Dolomite formation by nano-crystal aggregation in the Dolomia Principale of the Brenta Dolomites (Northern Italy), Riv. Ital. Paleontol. S., 125, 183-196, 2019.

Meister, P., Reyes, C., Beaumont, W., Rincon, M., Collins, L., Berelson, W., Stott, L., Corsetti, F., and Nealson, K. H.: Calcium- and magnesium-limited dolomite precipitation at Deep Springs Lake, California, Sedimentology, 58, 1810-1830, https://doi.org/10.1111/j.1365-3091.2011.01240.x, 2011.

More, K. D., Giosan, L., Grice, K., and Coolen, M. J.: Holocene paleodepositional changes reflected in the sedimentary microbiome of the Black Sea, Geobiology, 17, 436-448, https://doi.org/10.1111/gbi.12338, 2019.

Moreira, N., Walter, L. M., Vasconcelos, C., McKenzie, J. A., and McCall, P.: Role of sulfide oxidation in dolomitization: Sediments and pore-water geochemistry of a modern hypersaline lagoon system, Geology, 32, 701-704, https://doi.org/10.1130/g20353.1, 2004.

Moser, I.: Der abgetrocknete Boden des Neusiedler See's, Jahrbuch der Kaiserlich-Königlichen Geologischen Reichsanstalt Wien, 16, 338-344, 1866.

Müller, G., Irion, G., and Förstner, U.: Formation and diagenesis of inorganic $\mathrm{Ca}-\mathrm{Mg}$ carbonates in the lacustrine environment, Naturwissenschaften, 59, 158-164, https://doi.org/10.1007/bf00637354, 1972.

Neuenschwander, S. M., Ghai, R., Pernthaler, J., and Salcher, M. M.: Microdiversification in genome streamlined ubiquitous freshwater Actinobacteria, ISME J., 12, 185-198, https://doi.org/10.1038/ismej.2017.156, 2018.

Neuhuber, F.: Ein Beitrag zum Chemismus des Neusiedler Sees, Sitzungsberichte der Akademie der Wissenschaften in Wien, mathematisch-naturwissenschaftliche Klasse, Abteilung 1, 179, 225-231, 1971.

Neuhuber, S., Steier, P., Gier, S., Draganits, E., and Kogelbauer, I.: Radiogenic Carbon Isotopes in Authigenic Carbonate from Lake Neusiedl, Austria, EGU General Assembly Conference Abstracts, 2015.
Niedermayr, A., Köhler, S. J., and Dietzel, M.: Impacts of aqueous carbonate accumulation rate, magnesium and polyaspartic acid on calcium carbonate formation $\left(6-40^{\circ} \mathrm{C}\right)$, Chem. Geol., 340, 105-120, https://doi.org/10.1016/j.chemgeo.2012.12.014, 2013.

Parkhurst, D. L. and Appelo, C.: Description of input and examples for PHREEQC version 3: a computer program for speciation, batch-reaction, one-dimensional transport, and inverse geochemical calculations, US Geological Survey, 2328-7055, https://doi.org/10.3133/tm6a43, 2013.

Piller, W. E., Harzhauser, M., and Mandic, O.: Miocene Central Paratethys stratigraphy-current status and future directions, Stratigraphy, 4, 151-168, 2007.

Quast, C., Pruesse, E., Yilmaz, P., Gerken, J., Schweer, T., Yarza, P., Peplies, J., and Glöckner, F. O.: The SILVA ribosomal RNA gene database project: improved data processing and web-based tools, Nucl. Acid. Res., 41, D590, https://doi.org/10.1093/nar/gks1219, 2012.

R Core Team: RStudio: integrated development for R (RStudio, Inc., Boston, MA, USA), 2016.

R Core Team: R: A language and environment for statistical computing, R Foundation for Statistical Computing, available at: https://www.r-project.org (last access: 10 April 2020), 2019.

Rivadeneyra, M. a. A., Delgado, G., Soriano, M., RamosCormenzana, A., and Delgado, R.: Precipitation of carbonates by Nesterenkonia halobia in liquid media, Chemosphere, 41, 617624, https://doi.org/10.1016/s0045-6535(99)00496-8, 2000.

Roberts, J. A., Bennett, P. C., González, L. A., Macpherson, G., and Milliken, K. L.: Microbial precipitation of dolomite in methanogenic groundwater, Geology, 32, 277-280, https://doi.org/10.1130/g20246.2, 2004.

Rognes, T., Flouri, T., Nichols, B., Quince, C., and Mahé, F.: VSEARCH: a versatile open source tool for metagenomics, Peer J., 4, e2584, https://doi.org/10.7717/peerj.2584, 2016.

Rosen, M. R., Miser, D. E., Starcher, M. A., and Warren, J. K.: Formation of dolomite in the Coorong region, South Australia, Geochim. Cosmochim. Ac., 53, 661-669, https://doi.org/10.1016/0016-7037(89)90009-4, 1989.

Ryves, D. B., Battarbee, R. W., Juggins, S., Fritz, S. C., and Anderson, N. J.: Physical and chemical predictors of diatom dissolution in freshwater and saline lake sediments in North America and West Greenland, Limnol. Oceanogr., 51, 1355-1368, https://doi.org/10.4319/lo.2006.51.3.1355, 2006.

Sánchez-Román, M., Vasconcelos, C., Warthmann, R., Rivadeneyra, M., McKenzie, J. A., and Swart, P.: Microbial dolomite precipitation under aerobic conditions: results from Brejo do Espinho Lagoon (Brazil) and culture experiments, in: Perspectives in Carbonate Geology: A Tribute to the Career of Robert Nathan Ginsburg, edited by: Swart, P. K., Eberli, G. P., McKenzie, J. A., Jarvis, I., and Stevens, T., IAS Special Publication, 41, 167-178, https://doi.org/10.1002/9781444312065, 2009.

Schiemer, F. and Weisser, P.: Zur Verteilung der submersen Makrophyten in der schilffreien Zone des Neusiedler Sees, Sitzungsberichte der Akademie der Wissenschaften in Wien, mathematische-naturwissenschaftliche Klasse, Abteilung 1., 180, 87-97, 1972.

Schneider, D., Wemheuer, F., Pfeiffer, B., and Wemheuer, B.: Extraction of total DNA and RNA from marine filter samples and generation of a cDNA as universal template for marker gene 
studies, in: Metagenomics, edited by: Streit, W. and Daniel, R., Springer, Berlin, 13-22, https://doi.org/10.1007/978-1-49396691-2_2, 2017.

Schroll, E. and Wieden, P.: Eine rezente Bildung von Dolomit im Schlamm des Neusiedler Sees, Tscher. Miner. Petrog., 7, 286289, https://doi.org/10.1007/bf01127917, 1960.

Seeberg-Elverfeldt, J., Schlüter, M., Feseker, T., and Kölling, M.: Rhizon sampling of porewaters near the sediment-water interface of aquatic systems, Limnol. Oceanogr.-Method., 3, 361371, https://doi.org/10.4319/lom.2005.3.361, 2005

Soetaert, K., Hofmann, A. F., Middelburg, J. J., Meysman, F. J., and Greenwood, J.: The effect of biogeochemical processes on $\mathrm{pH}$, Mar. Chem., 105, 30-51, https://doi.org/10.1016/j.marchem.2007.06.008, 2007.

Steiner, Z., Lazar, B., Erez, J., and Turchyn, A. V.: Comparing Rhizon samplers and centrifugation for pore- water separation in studies of the marine carbonate system in sediments, Limnol. Oceanogr.-Method., 16, 828-839, https://doi.org/10.1002/lom3.10286, 2018.

Sun, J., Steindler, L., Thrash, J. C., Halsey, K. H., Smith, D. P., Carter, A. E., Landry, Z. C., and Giovannoni, S. J.: One carbon metabolism in SAR11 pelagic bacteria, PloS one, 6, e23973, https://doi.org/10.1371/journal.pone.0023973, 2011.

Systat Software: SigmaPlot for Windows, version 11.0, 2008.

Thompson, J. and Ferris, F.: Cyanobacterial precipitation of gypsum, calcite, and magnesite from natural alkaline lake water, Geology, 18, 995-998, 1990.

van Husen, D.: Quaternary glaciations in Austria, in: Quaternary Glaciations - Extent and Chronology, Part I, Europe, Developments in Quaternary Science, 2, Elsevier, Amsterdam, 1-13, https://doi.org/10.1016/s1571-0866(04)80051-4, 2004.

van Lith, Y., Vasconcelos, C., Warthmann, R., Martins, J .C. F., and McKenzie, J. A.: Bacterial sulfate reduction and salinity: two controls on dolomite precipitation in Lagoa Vermelha and Brejo do Espinho (Brazil), Hydrobiologia, 485, 35-49, https://doi.org/10.1007/s00792-005-0441-8, 2002.

Vasconcelos, C., McKenzie, J. A., Bernasconi, S., Grujic, D., and Tiens, A. J.: Microbial mediation as a possible mechanism for natural dolomite formation at low temperatures, Nature, 377, 220-222, https://doi.org/10.1038/377220a0, 1995.

Vasconcelos, C. and McKenzie, J. A.: Microbial mediation of modern dolomite precipitation and diagenesis under anoxic conditions (Lagoa Vermelha, Rio de Janeiro, Brazil), J. Sediment. Res., 67, 378-390, https://doi.org/10.1306/d42685772b26-11d7-8648000102c1865d, 1997. von Breymann, M. T., Collier, R., and Suess, E.: Magnesium adsorption and ion exchange in marine sediments: A multicomponent model, Geochim. Cosmochim. Ac., 54, 3295-3313, https://doi.org/10.1016/0016-7037(90)90286-t, 1990.

von der Borch, C. C., Lock, D. E., and Schwebel, D.: Groundwater formation of dolomite in the Coorong region of South Australia, Geology, 3, 283-285, https://doi.org/10.1130/00917613(1975)3<283:gfodit>2.0.co;2, 1975.

von Hoyningen-Huene, A. J. E., Schneider, D., Fussmann, D., Reimer, A., Arp, G., and Daniel, R.: Bacterial succession along a sediment porewater gradient at Lake Neusiedl in Austria, Sci Data, 6, 163, https://doi.org/10.1038/s41597-019-0172-9, 2019.

Warren, J. K.: Sedimentology and mineralogy of dolomitic Coorong lakes, South Australia, J. Sediment. Res., 60, 843-858, https://doi.org/10.1306/212f929b-2b24-11d7$8648000102 \mathrm{c} 1865 \mathrm{~d}, 1990$.

Whitman, W. B.: Bergey's manual of systematics of Archaea and Bacteria, Wiley Online Library, 19-1314, 2015.

Wolfram, G.: Bedeutung und Vorkommen von Salzlebensräumen, in: Salzlebensräume in Österreich, edited by: Wolfram, G., Zulka, K. P., Albert, R., Danihelka, J., Eder, E., Fröhlich, W. Holzer, T., Holzinger, W. E., Huber, H.-J., Korner, I., Lang, A., Mazzucco, K., Milasowszky, N., Oberleitner, I., Rabitsch, W., Sauberer, N., Schagerl, M., Schlick-Steiner, B. C., Steiner, F. M. and Steiner, K.-H., Umweltbundesamt, Wien, 13-26, 2006.

Wolfram, G. and Herzig, A.: Nährstoffbilanz Neusiedler See, Wiener Mitteilungen, 228, 317-338, 2013.

Wright, D. T. and Wacey, D.: Precipitation of dolomite using sulphate-reducing bacteria from the Coorong Region, South Australia: significance and implications, Sedimentology, 52, 9871008, https://doi.org/10.1111/j.1365-3091.2005.00732.x, 2005.

Zámolyi, A., Salcher, B., Draganits, E., Exner, U., Wagreich, M., Gier, S., Fiebig, M., Lomax, J., Surányi, G., and Diel, M.: Latest Pannonian and Quaternary evolution at the transition between Eastern Alps and Pannonian Basin: new insights from geophysical, sedimentological and geochronological data, Int. J. Earth Sci., 106, 1695-1721, https://doi.org/10.1007/s00531-016-13833, 2017.

Zhang, F., Yan, C., Teng, H. H., Roden, E. E., and Xu, H.: In situ AFM observations of $\mathrm{Ca}-\mathrm{Mg}$ carbonate crystallization catalyzed by dissolved sulfide: Implications for sedimentary dolomite formation, Geochem. Cosmochem. Ac., 105, 44-55, https://doi.org/10.1016/j.gca.2012.11.010, 2013.

Zhang, J., Kobert, K., Flouri, T., and Stamatakis, A.: PEAR: a fast and accurate Illumina Paired-End reAd mergeR, Bioinformatics, 30, 614-620, https://doi.org/10.1093/bioinformatics/btt593, 2013. 